\title{
Spiders from Vietnam (Arachnida: Aranei): new species and records
}

\section{Пауки из Вьетнама (Arachnida: Aranei): новые виды и находки}

\author{
D.V. Logunov ${ }^{1}$, P. Jäger ${ }^{2}$ \\ A.B. Могунов ${ }^{1}$, П. Егер $^{2}$ \\ 1 The Manchester Museum, The University of Manchester, Oxford Road, Manchester M13 9PL, UK. E-mail:
dmitri.v.logunov@manchester.ac.uk
${ }^{2}$ Senckenberg Research Institute, Senckenberganlage 25, 60325 Frankfurt am Main, Germany. E-mail: peter.jaeger@senckenberg.de
}

KEY WORDS: Spiders, Araneae, Vietnam, fauna, (re)descriptions, taxonomy, synonymy.

КЛЮЧЕВЫЕ СЛОВА: пауки, Araneae, Вьетнам, (пере)описания, таксономия, синонимия.

ABSTRACT. A total of 51 spider species collected from Vietnam is considered, of which seven are described as new: Araneidae: Argiope abramovi sp.n. (†); Clubionidae: Nusatidia vietnamensis sp.n. (†); Selenopidae: Selenops ab sp.n. ( $\left.\sigma^{7}\right)$; Sparassidae: Pseudopoda ohne sp.n. $\left(\sigma^{7}\right)$, Thelcticopis buu sp.n. $\left(\sigma^{T}\right)$; Thomisidae: Lysiteles vietnamensis sp.n. $\left(\sigma^{7}+\right.$ ); Salticidae: Pancorius crinitus sp.n. ( $O_{+}^{7}$ ). The genus Lechia Żabka, 1985 is synonymized with Laufeia Simon, 1889 (Salticidae). A new species synonymy is established: Pseudopoda houaphan Jäger, 2007 with P. namkhan Jäger, Pathoumthong et Vedel, 2006 (Sparassidae). A new combination is proposed: Laufeia squamata (Żabka, 1985), comb.n., ex Lechia (Salticidae). Unknown sexes are described for two species: Laufeia squamata (Żabka, 1985) ( $\left.\sigma^{7}\right)$, Ptocasius weyersi Simon, 1885 (†) (Salticidae). The following 16 species are reported for the spider fauna of Vietnam for the first time: Theridiidae: Phycosoma sinica (Zhu, 1992), Steatoda cingulata (Thorell, 1890); Tetragnathidae: Leucauge tessellata (Thorell, 1887), Orsinome vethi (Hasselt, 1842), Tetragnatha geniculata Karsch, 1892; Araneidae: Argiope jinghongensis Yin, Peng et Wang, 1994, Macracantha arcuata (Fabricius, 1793); Sparassidae: Pseudopoda namkhan Jäger, Pathoumthong et Vedel, 2006; Thomisidae: Lysiteles conicus Tang, Yin, Peng, Ubick et Griswold, 2007, L. dentatus Tang, Yin, Peng, Ubick et Griswold, 2007, L. punctiger Ono, 2001, L. torsivus Zhang, Zhu et Tso, 2006, Xysticus croceus Fox, 1937; Salticidae: Portia fimbriata (Doleschall, 1859), P. labiata (Thorell, 1887), Ptocasius weyersi Simon, 1885.

РЕЗЮМЕ. В статье рассмотрен 51 вид пауков, собранных во Вьетнаме, из которых семь описаны, как новые для науки: Argiope abramovi sp.n. (+); Clubionidae: Nusatidia vietnamensis sp.n. ( + ); Selenopidae: Selenops ab sp.n. $\left(\sigma^{7}\right)$; Sparassidae: Pseudopoda ohne sp.n. ( $\left.\sigma^{7}\right)$, Thelcticopis buu sp.n. $\left(\sigma^{7}\right)$; Thomisidae: Lysiteles vietnamensis sp.n. $\left(\bigcirc^{7}+\right)$; Salticidae: Pancorius crinitus sp.n. ( $\bigcirc^{7}$ ). Род Lechia Żabka, 1985 синонимизирован с Laufeia Simon, 1889
(Salticidae). Установлена видовая синонимия: Pseudopoda houaphan Jäger, 2007 c $P$. namkhan Jäger, Pathoumthong et Vedel, 2006 (Sparassidae). Предложена новая комбинация: Laufeia squamata (Żabka, 1985), comb.n., ex Lechia (Salticidae). Неизвестные пола описаны для двух видов: Laufeia squamata (Żabka, 1985) $\left(\mathrm{O}^{\top}\right)$, Ptocasius weyersi Simon, 1885 ( + ) (Salticidae). Следующие 16 видов указаны для фауны пауков Вьетнам впервые: Theridiidae: Phycosoma sinica (Zhu, 1992), Steatoda cingulata (Thorell, 1890); Tetragnathidae: Leucauge tessellata (Thorell, 1887), Orsinome vethi (Hasselt, 1842), Tetragnatha geniculata Karsch, 1892; Araneidae: Argiope jinghongensis Yin, Peng et Wang, 1994, Macracantha arcuata (Fabricius, 1793); Sparassidae: Pseudopoda namkhan Jäger, Pathoumthong et Vedel, 2006; Thomisidae: Lysiteles conicus Tang, Yin, Peng, Ubick et Griswold, 2007, L. dentatus Tang, Yin, Peng, Ubick et Griswold, 2007, L. punctiger Ono, 2001, L. torsivus Zhang, Zhu et Tso, 2006, Xysticus croceus Fox, 1937; Salticidae: Portia fimbriata (Doleschall, 1859), P. labiata (Thorell, 1887), Ptocasius weyersi Simon, 1885.

\section{Introduction}

The spider fauna of Vietnam is currently under intensive taxonomic and faunistic studies. It was recently reviewed by Ono et al. [2012], who listed 456 spider species. Since that time, some 50 additional spider species have been added to or described from Vietnam in the following families: Atypidae, one species [Zha et al., 2012]; Hahniidae, five species [Zhang et al., 2013]; Mysmenidae, three species [Lin, Li, 2014]; Nemesiidae, one species [Li, Zonstein, 2015]; Oonopidae, two species [Tong, Li, 2013]; Pholcidae, 27 species [Yao et al., 2012, 2015; Pham, 2015]; Psechridae, four species [Bayer, 2014]; Sparassidae, three species [Jäger, 2008; Eusemann, Jäger, 2009; Pham, 2012]; Thomisidae, one species [Benjamin, 2013]; and Zodariidae, three species [Dankittipakul et al., 2012]. Thus, to date a total of 506 
spider species has been reported from Vietnam, a number that beyond doubts represents a small proportion of the real spider diversity of the country.

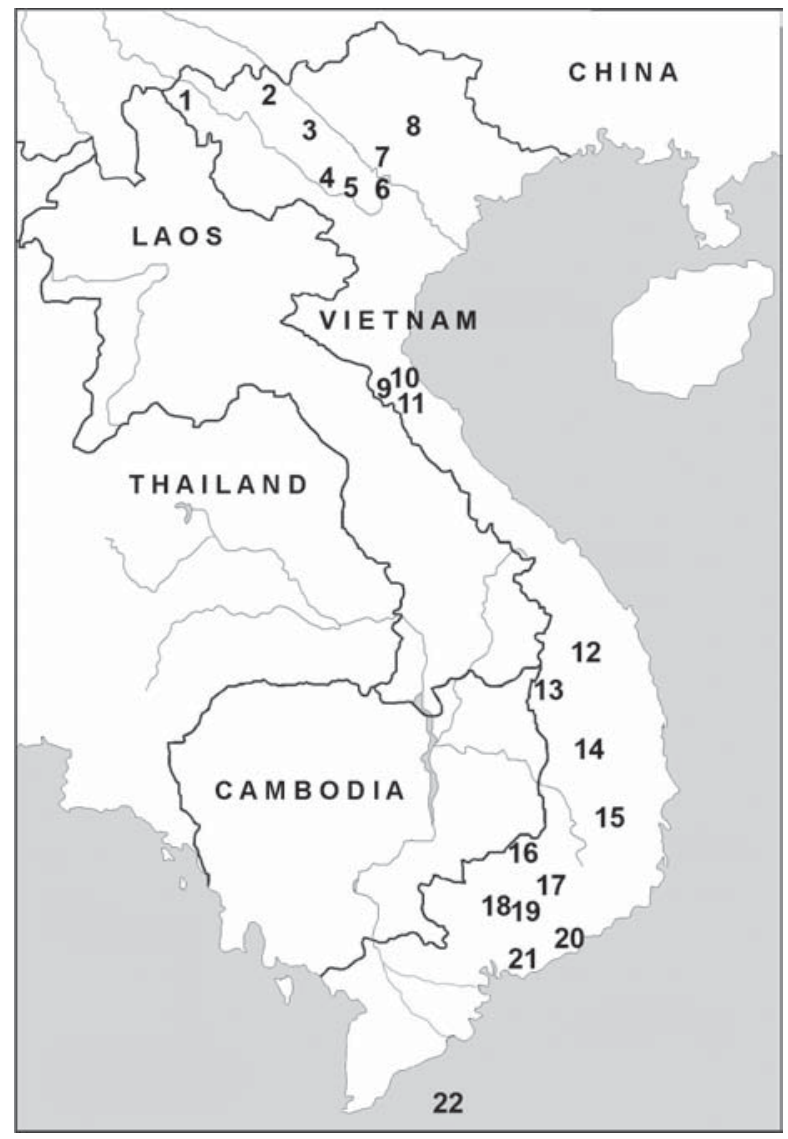

Map. Collecting localities of the spider material studied in the present paper: 1 - Dien Bien Prov., Muong Nhe Distr.; 2 - Lao Cai Prov., Hoang Lien Nat. Park; 3 - Lao Cai Prov., Van Ban Distr.; 4 - Son La Prov., Phu Yen Distr.; 5 - Phu Tho Prov., Xuan Son Nat. Park; 6 - Ba Vi Distr., Ba Vi Nat. Park; 7 - Vinh Phuc Prov., Vinh Yen Distr., Tam Dao; 8 - Lang Son Prov., Huu Lien Nat. Res.; 9 Ha Tinh Prov., Huong Son Distr.; 10 - Ha Tinh Prov., Hong Linh; 11 - Ha Tinh Prov., Ke Go Nat. Res.; 12 - Kon Tum Prov., Kon Plong Distr.; 13 - Kon Tum Prov., Chu Mom Ray Nat. Park; 14 the border between Gia Lai and Dak Lak Provinces; 15 - Dak Lak Prov., Chu Yang Sin Nat. Park; 16 - Binh Phuoc Prov., Bu Gia Map Nat. Park; 17 - Lam Dong Prov., Loc Bao Distr.; 18 - Dong Nai Prov., Vinh Cuu Nat. Res.; 19 - Dong Nai Prov., Cat Tien Nat. Park; 20 - Binh Thuan Prov., Phan Thiet; 21 - Ba Ria - Vung Tau Prov., Binh Chau - Phuoc Buu Nat. Res.; 22 - Ba Ria - Vung Tau Prov., Central part of Con Son Island.

Карта. Точки сбора материала по паукам, изученного в настоящей статье: 1 - пров. Дьенбьен, округ Муонгне; 2 пров. Лаокай, нац. парк Хоанглиен; 3 - пров. Лаокай, округ Ванбан; 4 - пров. Шонла, округ Фуен; 5 - пров. Футо, нац. парк Суансон; 6 - округ Бави, нац. парк Бави; 7 - пров. Виньфук, округ Виньен, Тамдао; 8 - пров. Лангсон, нац. парк Хуулиен; 9 - пров. Хатинь, округ Хуонгсон; 10 - пров. Хатинь, Хонглинь; 11 - пров. Хатинь, заповедник Кего; 12 - пров. Контум, округ Конплонг; 13 - пров. Контум, нац. парк Чумомрай; 14 - граница между провинциями Зялай и Даклак; 15 - пров. Даклак, нац. парк Чуянгсин; 16 - пров. Биньфуок, нац. парк Бузямап; 17 - пров. Ламдонг, округ Локбао; 18 пров. Донгнай, заповедник Винькуу; 19 - пров. Донгнай, нац. парк Катьен; 20 - пров. Биньтуан, Фантьет; 21 - пров. БариаВунгтау, заповедник Биньчау-Фуокбуу; 22 - пров. БариаВунгтау, центр. часть о-ва Коншон.
The aims of the present paper are: (1) to describe seven new spider species from Vietnam; (2) to describe unknown sexes for two species; (3) to establish new species and generic synonymies; and (4) to provide new faunistic records for 45 spider species, of which 16 are recorded from Vietnam for the first time.

\section{Material and methods}

This work is based on museum and private spider collections, of which the bulk of studied specimens was collected by Dr Alexei V. Abramov (Zoological Institute RAS, St. Petersburg) during a number of field trips to Vietnam (2000-2015; see Map) supported by the Russian-Vietnamese Tropical Centre. A total of 173 adult specimens belonging to 51 spider species has been studied and included in this paper. The studied material has been borrowed from or deposited in the following museums: BMNH - British Museum of Natural History, London, UK (J. Beccaloni); MMUE — The Manchester Museum, University of Manchester, Manchester, UK (D.V. Logunov); PSU - Zoological Department of the Perm State University, Perm, Russia (S.L. Esyunin); RMNH Rijksmuseum von Naturlijke Historie Naturalis, Leiden, The Netherlands (K. van Dorp, J. Miller); SMF Senckenberg Research Institute, Frankfurt am Main, Germany (J. Altmann, P. Jäger); ZMMU - Zoological Museum of the Moscow University, Moscow, Russia (K.G. Mikhailov).

In the following annotated list of species, all the collecting localities are given in the order presented on the map (from north to south), and the numbers in square brackets following the detailed information on each locality correspond to those given on the map.

Abbreviations used in the text: Copulatory organs: RTA - retrolateral tibial apophysis, VTA — ventral tibial apophysis. Body measurements: AW - anterior width of prosoma, OL - opisthosoma length, OW opisthosoma width, PL — prosoma length, PW prosoma width. Eyes and eye interdistances: ALE anterior lateral eye, AME - anterior median eye, MOA - median ocular area, MOA-L — length of MOA, MOA-WA - anterior width of MOA, MOAWP - posterior width of MOA, PLE - posterior lateral eye, PME - posterior median eye. Legs and leg segments: I-IV - legs I, II, III and IV, Fm femur, Mt - metatarsus, $\mathrm{Pt}$ - patella, $\mathrm{Tb}$ - tibia, $\mathrm{Tr}$ - tarsus. Position of spines on legs: ap — apical, $\mathrm{d}$ - dorsal, pr - prolateral, $\mathrm{rt}$ - retrolateral, $\mathrm{v}$ ventral. Other abbreviations: a.s.1. — above sea level, Nat. - National, nr. - near, Vil. - village. For the leg spination and terminology presented in the (re)descriptions of Salticidae and Thomisidae the system adopted is that used by Ono [1988], for Clubionidae, Selenopidae and Sparassidae that used by Davies [1994]. The sequence of leg segments in measurement data is as follows: femur + patella + tibia + metatarsus + tarsus. All measurements are in millimetres. 


\section{Survey of species}

\section{Theridiidae}

Phycosoma sinica (Zhu, 1992)

MATERIAL. VIETNAM: 1 (ZMMU), Vinh Phuc Prov., Vin Yen Distr., nr. Tam Dao Town $\left(21^{\circ} 27^{\prime} 20^{\prime \prime} \mathrm{N}, 105^{\circ} 38^{\prime} 37^{\prime \prime}\right.$ E) [7], 900 m a.s.1., 27.04.2000, A.V. Abramov.

COMMENTS. To date, this species has been known from China only [WSC, 2015]; first record for Vietnam (Map: 7).

\section{Steatoda cingulata (Thorell, 1890)}

MATERIAL. VIETNAM: $10^{\top}$ (ZMMU), Phu Tho Prov., Thanh Son Distr., Xuan Son Nat. Park $\left(21^{\circ} 08^{\prime} 11^{\prime \prime} N, 104^{\circ} 56^{\prime} 11^{\prime \prime}\right.$ E) [5], 300-400 m a.s.1., July 2014, A.V. Abramov.

COMMENTS. Oriental species, known from Korea and Japan in the north, southward throughout China and Laos to Indonesia (Sumatra, Java) [WSC, 2015]; first record for Vietnam (Map: 5).

\section{Tetragnathidae}

Leucauge celebesiana (Walckenaer, 1841)

MATERIAL. VIETNAM: $1 \sigma^{7}$ (ZMMU), Lao Cai Prov., Van

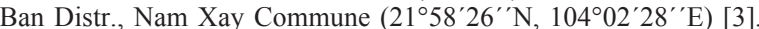
900-1200 m a.s.1., 19.03-15.04.2005, A.V. Abramov; 4 우 (MMUE, G7565.10), Kon Tum Prov., Kon Plong Distr., c. 14 km N of Kon Plong Town $\left(14^{\circ} 43^{\prime} 20^{\prime \prime} \mathrm{N}, 108^{\circ} 18^{\prime} 58^{\prime \prime} \mathrm{E}\right)$ [12], $1030 \mathrm{~m}$ a.s.l., 923.04.2015 A.V. Abramov; 1 + (ZMMU), Dak Lak Prov., Krong Kmar Distr., Chu Yang Sin Nat. Park $\left(12^{\circ} 23^{\prime} 48^{\prime \prime}\right.$ N, 108 $20^{\prime} 59^{\prime \prime}$ E) [15], $1000 \mathrm{~m}$ a.s.l., April 2012, A.V. Abramov; 1 o (MMUE, G7565.11), Lam Dong Prov., Loc Bao Distr., c. $35 \mathrm{~km} N$ of Bao Loc Town $\left(11^{\circ} 50^{\prime} 12^{\prime \prime} \mathrm{N}, 107^{\circ} 38^{\prime} 25^{\prime \prime} \mathrm{E}\right)$ [17], $650 \mathrm{~m}$ a.s.l., April-May 2012, A.V. Abramov.

COMMENTS. Widespread Oriental species, known from southern India in the west to Japan in the east, and from the Russian Far East (Maritime Territory) in the north to New Guinea in the south [Marusik, Kovblyuk, 2011; WSC, 2015]; hitherto recorded from Vietnam ("Cam-Nang") by Simon [1909; see Ono et al., 2012].

\section{Leucauge tessellata (Thorell, 1887)}

MATERIAL. VIETNAM: 2 ㅇ (MMUE, G7565.9), Ba Vi Distr., c. $50 \mathrm{~km} \mathrm{~W}$ of Hanoi, Ba Vi Nat. Park, nr. Tanh Linh Vil. $\left(21^{\circ} 05^{\prime} 49.6^{\prime \prime} \mathrm{N}, 105^{\circ} 24^{\prime} 07.3^{\prime \prime} \mathrm{E}\right)$ [6], $100 \mathrm{~m}$ a.s.1., May 2013, A.V. Abramov; 1 ( (ZMMU), Ha Tinh Prov., Huong Son Distr., Son Kim Commune, c. $10 \mathrm{~km} \mathrm{~S}$ of Nuoc Sot Vil. $\left(18^{\circ} 22^{\prime} \mathrm{N}, 105^{\circ} 13^{\prime} \mathrm{E}\right)$ [9], 200 m a.s.1., 11-26.04.2000, A.V. Abramov.

COMMENTS. Oriental species, known from India in the west, throughout southern China (Yunnan), to Vietnam (present data), Taiwan and Moluccas [WSC, 2015]; first record for Vietnam (Map: 6, 9).

\section{Orsinome vethi (Hasselt, 1842)}

MATERIAL. VIETNAM: $6 \sigma^{7} \sigma^{7}, 7$ 우 (ZMMU), Ha Tinh Prov., Huong Son Distr., Son Kim Commune, c. $10 \mathrm{~km} \mathrm{~S} \mathrm{of} \mathrm{Nuoc}$ Sot Vil. $\left(18^{\circ} 22^{\prime} \mathrm{N}, 105^{\circ} 13^{\prime} \mathrm{E}\right)$ [9], $200 \mathrm{~m}$ a.s.l., 11-26.04.2000, A.V. Abramov.

COMMENTS. Oriental species, known from southern China and Laos to Malaysia and Indonesia (Sumatra, Java and Flores) [WSC, 2015]; first record for Vietnam (Map: 9).

\section{Tetragnatha geniculata Karsch, 1892}

MATERIAL. VIETNAM: 1 (ZMMU), Dak Lak Prov., Krong Kmar Distr., Chu Yang Sin Nat. Park $\left(12^{\circ} 25^{\prime} 26^{\prime \prime} \mathrm{N}, 108^{\circ} 21^{\prime} 52^{\prime \prime} \mathrm{E}\right)$ [15], 950 m a.s.l., May 2014, A.V. Abramov.

COMMENTS. To date, this Oriental species has been known from Sri Lanka, southern China and Laos [Jäger, Praxaysombath, 2009; WSC, 2015]; first record for Vietnam (Map: 15).

\section{Nephiliidae}

Herennia multipuncta (Doleschall, 1859)

MATERIAL. VIETNAM: 1 (MMUE), Dien Bien Prov., Muong Nhe Distr., Sin Thau Commune $\left(22^{\circ} 21^{\prime} 54^{\prime \prime} \mathrm{N}, 102^{\circ} 14^{\prime} 15^{\prime \prime} \mathrm{E}\right)$ [1], $800 \mathrm{~m}$ a.s.l., June 2014, A.V. Abramov; 2 우 (ZMMU), Ha Tinh Prov., Cam Xuyen Distr., Ke Go Nat. Res., nr. Mui Tru Station $\left(18^{\circ} 06^{\prime} 30^{\prime \prime} \mathrm{N}, 106^{\circ} 01^{\prime} 01^{\prime \prime} \mathrm{E}\right)$ [11], $40 \mathrm{~m}$ a.s.1., 7-14.04.2015 A.V. Abramov.

COMMENTS. Common Oriental species, known from India and Nepal in the west to the Philippines in the east, south-eastward to Indonesia (Sumatra, Borneo, Sumatra, etc.) [Kuntner, 2005; WSC, 2015]; hitherto recorded from Vietnam (Annam, Annam Region) by Kuntner [2005].

Nephila pilipes (Fabricius, 1793)

MATERIAL. VIETNAM: 3 오 (MMUE, G7565.1), Phu Tho Prov., Thanh Son Distr., Xuan Son Nat. Park $\left(21^{\circ} 08^{\prime} 11^{\prime \prime} \mathrm{N}\right.$, $104^{\circ} 56^{\prime} 11^{\prime \prime}$ E) [5], 300-400 m a.s.1., July 2014, A.V. Abramov; 2 oᄋ (ZMMU), Ha Tinh Prov., Huong Son Distr., Son Kim Commune, c. $10 \mathrm{~km} \mathrm{~S}$ of Nuoc Sot Vil. $\left(18^{\circ} 22^{\prime} \mathrm{N}, 105^{\circ} 13^{\prime} \mathrm{E}\right)$ [9], $200 \mathrm{~m}$ a.s.l., 11-26.04.2000, A.V. Abramov.

COMMENTS. Widespread Oriental species, known from India in the west, throughout southern China (Guangdong, Beijing, Liaoning), to the Philippines in the east, southward to Australia [Song et al., 1999; WSC, 2015]; hitherto recorded from Vietnam (Luc-Nam, forest Maï-Xu, Tuyen Quang and south Annam) by Simon [1909: sub N. maculata] and Hogg [1922; see Ono et al., 2012].

\section{Araneidae}

Argiope abramovi Logunov et Jäger, sp.n. Figs 1-7

TYPE. Holotype + (ZMMU) from Vietnam, Kon Tum Prov., Kon Plong Distr., c. $14 \mathrm{~km} \mathrm{~N}$ of Kon Plong Town $\left(14^{\circ} 43^{\prime} 20^{\prime \prime} \mathrm{N}\right.$, $108^{\circ} 18^{\prime} 58^{\prime \prime}$ E) [12], $1030 \mathrm{~m}$ a.s.1., 09-23.04.2015, A.V. Abramov.

ETYMOLOGY. The species is named in honour of the collector of the holotype, Dr Alexei V. Abramov (Zoological Institute, St. Petersburg, Russia), who has been studying the Vietnamese vertebrate fauna for a long time and whose extensive spider material is partly included in this paper; the name in genitive case.

DIAGNOSIS. The female of Argiope abramovi sp.n. (Figs 5-7) is similar to that of A. perforata Schenkel, 1963 [cf. Song et al., 1999: figs $151, \mathrm{~V}, \mathrm{Y}-\mathrm{Z}$ ] in having a similar dorsal and ventral colour pattern, with two lateral bands on the prosoma, two white longitudinal patches laterally, two small humps anteriorly on the opisthosoma, a white trilobate sternal patch and ventral opisthosoma with six white patches between two lateral parallel bands, as well as a wide median epigynal septum (seen in posterior view). It can be distinguished from the latter species by the following characters: (1) the characteristic shape of the median septum as seen in ventral view (Fig. 1); (2) opisthosoma dorsally with a posterior dark part separated by a white median band (Fig. 5); (3) small white dots on the median field of venter are round (Fig. 6) rather than transversally elongated as in A. perforata.

DISTRIBUTION. The type locality only (Map: 12).

DESCRIPTION. MALE. Unknown.

FEMALE. Measurements. PL 3.2, PW 2.8, AW 1.5, OL 5.8, OW 4.1. Eye diameters: AME 0.18, ALE 0.13, PME 0.25, PLE 0.21. Eye interdistances: AME-AME 0.15, AME-ALE 0.18, PME-PME 0.31, PME-PLE 0.50, AME-PME 0.39, ALE-PLE 0.01, clypeus AME 0.14, clypeus ALE 0.13. Leg and pedipalp measurements: pedipalp 3.59 (1.15, 0.51, 0.67,, 1.26); Leg I 16.2 (4.8, 1.6, 3.9, 4.4, 1.5); Leg II 15.8 (4.8, 1.6, 3.8, 4.3, 1.3); Leg III 9.0 (3.0, 1.0, 1.9, 2.2, 0.9); Leg IV 14.2 
$(4.8,1.5,3.0,3.9,1.0)$. Leg formula: 1243 . Chelicerae with 4 anterior, 3 posterior teeth and ca. 30 partly tiny denticles. Palpal claw with 9 teeth. Coloration in ethanol (Figs 5-7). Body brown, with a dark brown pattern. Prosoma dorsally with a light median band, fovea marked with a brown patch; dark lateral bands with light striae. Sternum with a white median band, which is trilobate posteriorly. Chelicerae dark brown. Palps light brown, with only few dark bands. Legs darker, with a vivid pattern of large annulated parts and small dots. Opisthosoma dorsally with two large lateral white patches anteriorly and two longitudinal parallel dark bands posteriorly; laterally white in its anterior half and brown in its posterior one; ventrally with a wide dark median band carrying six small round dots of equal size, two longitudinal parallel white bands, and a lateral hump in the middle part. Spinnerets reddish brown. Copulatory organ as characterised in the diagnosis (Figs 1-4): the epigyne as wide as long, with two large cavities laterally and a median septum diverging posteriorly and with distinct wrinkles anteriorly; spermathecae elongated oval, parallel; fertilisation ducts originate posteriorly, folded.
Argiope jinghongensis Yin, Peng et Wang, 1994

MATERIAL. VIETNAM: 1 (ZMMU), Dak Lak Prov., Krong Kmar Distr., Chu Yang Sin Nat. Park (12 $23^{\prime} 48^{\prime \prime N}$, 108 $\left.20^{\prime} 59^{\prime \prime} \mathrm{E}\right)$ [15], 1000 m a.s.l., April 2012, A.V. Abramov.

COMMENTS. To date, the species has been recorded from a few localities in China (Yunnan), Laos and Thailand [Jäger, 2012a; WSC, 2015]; first record for Vietnam (Map: $15)$.

\section{Argiope pulchella Thorell, 1881}

MATERIAL. VIETNAM: 1 (ZMMU), Ha Tinh Prov., Huong Son Distr., Son Kim Commune, c. $10 \mathrm{~km} \mathrm{~S}$ of Nuoc Sot Vil. $\left(18^{\circ} 22^{\prime} \mathrm{N}, 105^{\circ} 13^{\prime} \mathrm{E}\right)$ [9], $200 \mathrm{~m}$ a.s.1., 11-26.04.2000, A.V. Abramov.

COMMENTS. Oriental species, known from India in the west, throughout southern China, to Indonesia (Sumatra, Java and West Nusa Tenggara) in the south-east [Jäger, 2012a; WSC, 2015]; hitherto recorded from Vietnam (PhuLang-Thuong of Song Luc Nam region) by Simon [1909; see Ono et al., 2012].
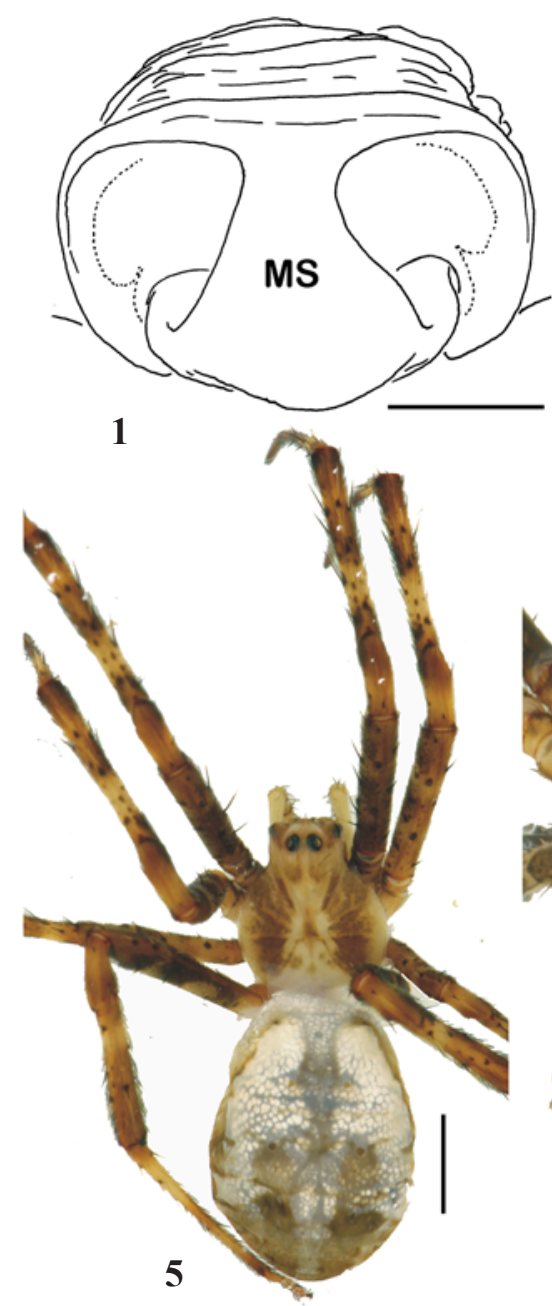

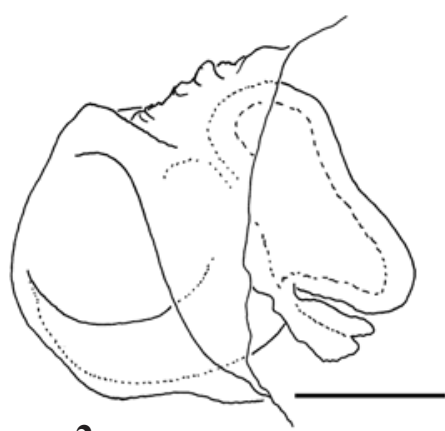

2

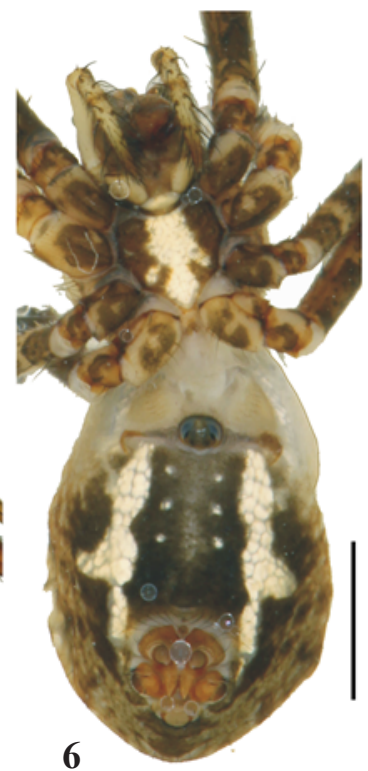

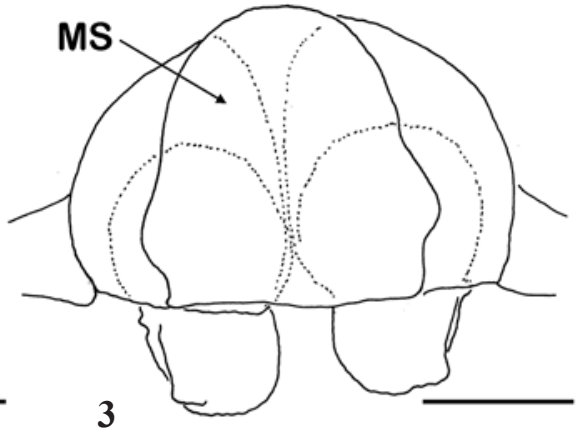

3

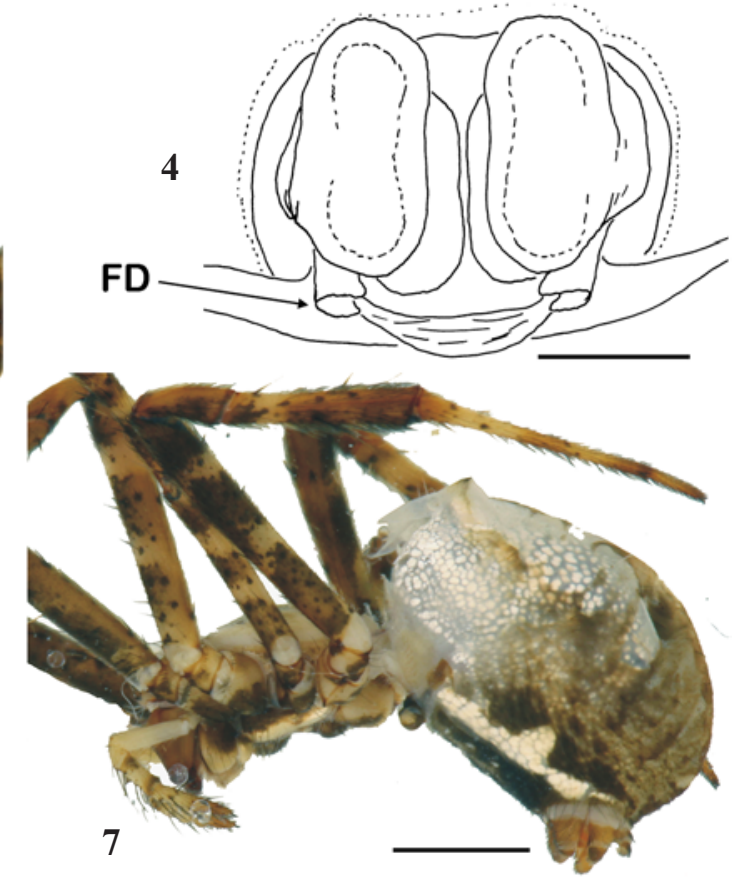

Figs 1-7. Copulatory organs and habitus of Argiope abramovi sp.n. ( $\$$ holotype), Araneidae: 1 - epigyne, ventral view; 2 - ditto, lateral view; 3 - ditto, posterior view; 4 - spermathecae, dorsal view; 5 - habitus, dorsal view; 6 - ditto, ventral view; 7 - ditto, lateral view. Scale bars: (1-4) $0.2 \mathrm{~mm}$, (5-7) $2 \mathrm{~mm}$. Abbreviations: FD - fertilization duct; MS - median septum.

Рис. 1-7. Копулятивные органы и габитус Argiope abramovi sp.n. († голотип), Araneidae: 1 — эпигина, вид снизу; 2 — тоже, сбоку; 3 - тоже, сзади; 4 - сперматека, вид сверху; 5 - габитус, вид сверху; 6 - тоже, снизу; 7 - тоже, сбоку. Масштаб: (1-4) 0,2 мм, (5-7) 2 мм. Сокращения: FD - оплодотворительный канал; MS - медиальный септум. 
Cyclosa nigra Yin, Wang, Xie et Peng, 1994

MATERIAL. VIETNAM: 1 (ZMMU), Ha Tinh Prov., Huong Son Distr., Son Kim Commune, c. $10 \mathrm{~km} \mathrm{~S}$ of Nuoc Sot Vil. $\left(18^{\circ} 22^{\prime} \mathrm{N}\right.$, $105^{\circ} 13^{\prime}$ E) [9], $200 \mathrm{~m}$ a.s.1., 11-26.04.2000, A.V. Abramov.

COMMENTS. To date, the species has been known from China (Yunnan) and Vietnam only [Ono et al., 2012; WSC, 2015]; hitherto recorded from Vietnam (Vinh Phuc Prov.) by Ono et al. [2012].

Macracantha arcuata (Fabricius, 1793)

MATERIAL. VIETNAM: 1 (ZMMU), Phu Tho Prov., Thanh

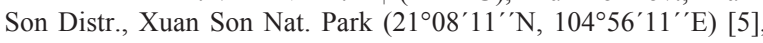
300-400 m a.s.l., July 2014, A.V. Abramov.

COMMENTS. Oriental species, known from India in the west, throughout southern China (Yunnan), to Indonesia (Sumatra) [Song et al., 1999; sub Gasteracantha a.; WSC, 2015]; first record for Vietnam (Map: 5).

\section{Parawixia dehaani (Doleschall, 1859)}

MATERIAL. VIETNAM: 1 + (ZMMU), Dien Bien Prov., Muong Nhe Distr., Sin Thau Commune $\left(22^{\circ} 21^{\prime} 54^{\prime \prime} \mathrm{N}\right.$, $102^{\circ} 14^{\prime} 15^{\prime \prime}$ E) [1], $800 \mathrm{~m}$ a.s.l., June 2014, A.V. Abramov; 1 \% (MMUE, G7565.7), Ha Tinh Prov., Huong Son Distr., Son Kim Commune, c. $10 \mathrm{~km} \mathrm{~S}$ of Nuoc Sot Vil. (18 $\left.22^{\prime} \mathrm{N}, 105^{\circ} 13^{\prime} \mathrm{E}\right)$ [9], $200 \mathrm{~m}$ a.s.1., 11-26.04.2000, A.V. Abramov; 1 ㅇ (ZMMU), Ha Tinh Prov., Cam Xuyen Distr., Ke Go Nat. Res., nr. Mui Tru Station $\left(18^{\circ} 06^{\prime} 30^{\prime \prime} \mathrm{N}, 106^{\circ} 01^{\prime} 01^{\prime \prime} \mathrm{E}\right)$ [11], $40 \mathrm{~m}$ a.s.1., $7-$ 14.04.2015 A.V. Abramov; 1 + (ZMMU), Kon Tum Prov., Kon Plong Distr., c. $14 \mathrm{~km} \mathrm{~N}$ of Kon Plong Town $\left(14^{\circ} 43^{\prime} 20^{\prime \prime} \mathrm{N}\right.$, $108^{\circ} 18^{\prime} 58^{\prime \prime}$ E) [12], $1030 \mathrm{~m}$ a.s.1., 9-23.04.2015, A.V. Abramov; 1 ( (MMUE, G7565.8), Kon Tum Prov., Eastern part of Chu Mom

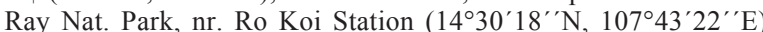
[13], 700 m a.s.1., 26.03-6.04.2015, A.V. Abramov.

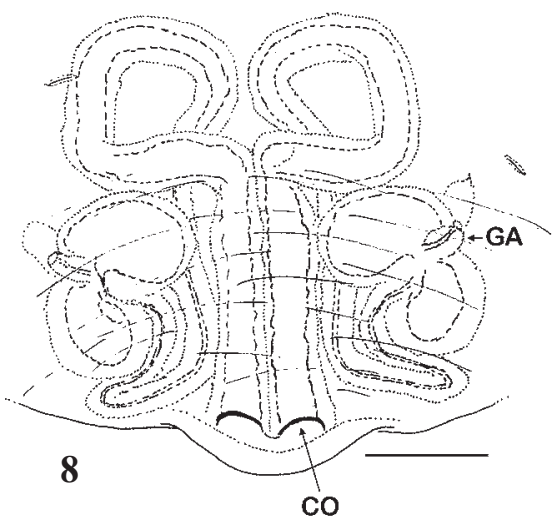

10

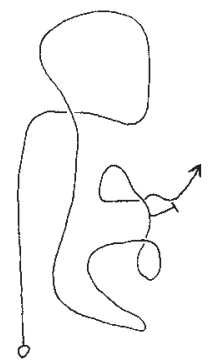

COMMENTS. Common Oriental species, known from India in the west to the Philippines in the east, south-eastward to New Guinea [WSC, 2015]; hitherto recorded from Vietnam (Song Luc Nam region and Port Wallut) by Simon [1887: sub Epeira submucronata; see Ono et al., 2012].

\section{Psechridae}

Fecenia protensa Thorell, 1891

MATERIAL. VIETNAM: 4 ㅇ (ZMMU), Ha Tinh Prov., Huong Son Distr., Son Kim Commune, c. $10 \mathrm{~km}$ S of Nuoc Sot Vil. $\left(18^{\circ} 22^{\prime} \mathrm{N}\right.$, $105^{\circ} 13^{\prime}$ E) [9], c. $200 \mathrm{~m}$ a.s.l., 11-26.04.2000, A.V. Abramov.

COMMENTS. Widespread Oriental species, known from India and Sri Lanka in the west, throughout southern Thailand and Vietnam, to Malaysia and Indonesia (Sumatra, Borneo, Bali) [WSC, 2015]; hitherto rerecorded from Vietnam (Yen Tu Mt. in Quang Ninh Prov.) by Bayer [2014].

\section{Clubionidae}

Nusatidia vietnamensis Logunov et Jäger, sp.n. Figs 8-10.

TYPE. Holotype 9 (ZMMU) from Vietnam, Lam Dong Prov., Loc Bao Distr., c. $35 \mathrm{~km} \mathrm{~N}$ of Bao Loc Vil. $\left(11^{\circ} 50^{\prime} 12^{\prime \prime} \mathrm{N}\right.$, $107^{\circ} 38^{\prime} 25^{\prime \prime}$ E) [17], $650 \mathrm{~m}$ a.s.1., 04-05.2012, A.V. Abramov.

COMPARATIVE MATERIAL. $N$. borneensis Deeleman-Reinhold, 2001 (Fig. 11): $10^{7}, 2$ +क (RMNH), N Borneo, Mt. Kinabalu, Nat. Park Poring Hot Springs, Loc. $3\left(6^{\circ} 2^{\prime} \mathrm{N}, 116^{\circ} 50^{\prime} \mathrm{E}\right)$, canopy fogging of Aporusa sp. (Euphorbiaceae), 23.02.1996, A. Floren, ex. coll. C.L. Deeleman-Reinhold: 2000: 704. - Nusatidia sp.: 2 +क (RMNH), Thailand, Khao Yai Nat. Park, secondary forest and forest near water fall, 2 4.03.1986, C.L. Deeleman-Reinhold \& P.R. Deeleman.

ETYMOLOGY. Named after the country of origin, Vietnam; adjective.

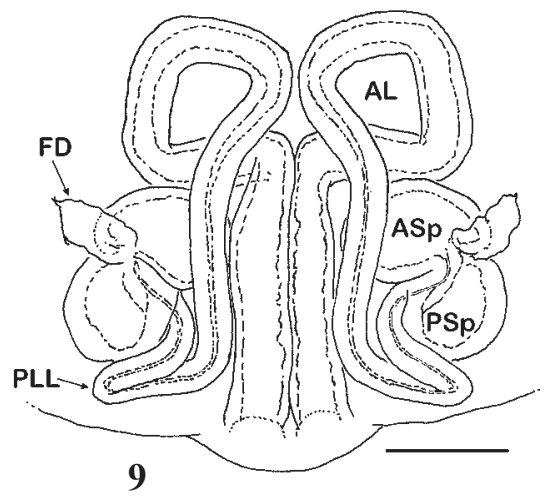

Figs 8-11. Female copulatory organs of Nusatidia vietnamensis sp.n. ( 9 holotype; 8-10) and N. borneensis Deeleman-Reinhold, 2001 from north Borneo (11), Clubionidae: 8,11 - epigyne, ventral view; 9 - spermathecae, dorsal view; 10 - diagrammatic course of the insemination ducts. Scale bars: $0.1 \mathrm{~mm}$. Abbreviations: AL — anterior loop; ASp — anterior spermathecae; CO — copulatory opening; FD - fertilization duct; GA — glandular appendage; PLL — posterior lateral loop; PSp — posterior spermathecae.

Рис. 8-11. Копулятивные органы Nusatidia vietnamensis sp.n. († голотип; 8-10) и N. borneensis Deeleman-Reinhold, 2001 из северного Борнео (11), Clubionidae: 8, 11 - эпигина, вид снизу; 9 - сперматека, вид сверху; 10 - схема протоков копулятивных протоков. Масштаб: 0,1 мм. Сокращения: AL — передняя петля; ASp — передняя сперматека; CO — копулятивное отверстие; FD - оплодотворительный канал; GA - железистый придаток; PLL - заднебоковая петля; PSp - задняя сперматека. 
DIAGNOSIS. By a similar ground plan of the female copulatory duct system, especially by the presence of the anterior loops, the new species is closely related to $N$. borneensis (cf. Deeleman-Reinhold [2001: figs 157-160] and Fig. 9), but can be distinguished by the following characters: (1) the relatively smaller anterior spermatheca, not covering the initial median part of the copulatory ducts and separated from each other by a distance equal to its diameter (in $N$. borneensis, the anterior spermatheca is larger, covering the copulatory ducts and separated by a distance much less than one third of its diameter or almost touching); (2) in ventral view, the copulatory openings are seen as semi-circles (full circles in $N$. borneensis or quite circular in N. vietnamensis sp.n., as seen from behind); (3) the copulatory ducts close before entering the spermathecae with distinct lateral loops (without such loops in N. borneensis).

DISTRIBUTION. The type locality only (Map: 17).

DESCRIPTION. MALE. Unknown.

FEMALE. Measurements. PL 2.6, PW 1.6, AW 0.9, OL 4.9, OW 1.7. Eye diameters: AME 0.09, ALE 0.12, PME 0.10 , PLE 0.12. Eye interdistances: AME-AME 0.07, AMEALE 0.05, PME-PME 0.24, PME-PLE 0.11, AME-PME 0.13, ALE-PLE 0.06, clypeus AME 0.04, clypeus ALE 0.05. Leg and pedipalp measurements: pedipalp $2.12(0.70,0.32$, $0.45,-, 0.65)$; leg I $7.0(2.1,0.9,2.0,1.3,0.7)$; leg II $7.9(2.4$, $1.0,2.2,1.6,0.7)$; leg III $6.1(1.8,0.7,1.5,1.5,0.6)$; leg IV $9.3(2.7,0.7,2.3,2.9,0.7)$. Leg formula. 4213. Spination: pedipalp Fm: 131, Pt 010, Tb 2121, Tr 1014; Fm I 230, II 231, III-IV 030; Pt I 021 (thin bristles); Tb I-II 0104, III 2122, IV 2224; Mt I-II 000, III 3125, IV 3236. Chelicerae with 3 anterior and 2 posterior teeth. Prosoma, opisthosoma including spinnerets and anal tubercle elongated as shown for N. camouflata [Deeleman-Reinhold, 2001: figs 169-170]. Coloration in ethanol. Prosoma and opisthosoma pale yellow, without a pattern. Fovea short, longitudinal, indistinctly marked with black. Copulatory organs as characterised in the diagnosis (Figs 8-10): copulatory openings are situated in the posterior half of the epigyne, close to the posterior margin and a semi-circular posterior extension; copulatory ducts run first medially and in parallel from the posterior to anterior ends, then bend at the right angle into the anterior loop and backwards along the initial part, after the posterior lateral loop run into the spermathecae; the second pair of the spermathecae present, membranous, situated postero-laterally; ventral glandular appendage and dorsal fertilization duct present at the anterior spermathecae, close to the connection between the anterior and the posterior spermathecae.

\section{Selenopidae}

Selenops $a b$ Logunov et Jäger, sp.n. Figs 12-16.

TYPE. Holotype $0^{7}$ (ZMMU) from Vietnam, Ha Tinh Prov., Huong Son Distr., Son Kim Commune, c. S of Nuoc Sot Vil. (18 $22^{\prime}$ M, $105^{\circ} 13^{\prime}$ E) [9], $200 \mathrm{~m}$ a.s.1., 11-26.4.2000, A.V. Abramov.

COMPARATIVE MATERIAL. Selenops bursarius Karsch, 1879 (Fig. 17): $4 O^{7} O^{7}, 2$ juveniles (SMF, 4742), Japan, Saga, 1882, W. Dönitz.

ETYMOLOGY. The specific name is an arbitrary combination of letters reflecting the small size of the new species by using the smallest number of letters to form a specific name; a noun in apposition.

DIAGNOSIS. It is a rather small species of the genus, with the body length $6.2 \mathrm{~mm}$. By the massive RTA arising proximally from the tibia (Figs 12-14), the male palp of Selenops ab sp.n. is similar to those of $S$. muehlmannorum Jäger et Praxaysombath, 2011 and S. bursarius Karsch, 1879 (cf. Jäger,
Praxaysombath [2011] and Fig. 17), from which it can be distinguished by the following characters: (1) the ventral and dorsal [retrolateral] branches of RTA are of roughly similar width and length as seen in ventral view (the dorsal [retrolateral] branch is distinctly longer than the ventral one in $S$. bursarius; the ventral branch is much wider than the dorsal one in S. muehlmannorum); and (2) the embolus is narrow (as seen in ventral view), arising from the tegulum at eight o'clockposition (broad in S. muehlmannorum; arising from the tegulum at six o'clock-position in S. bursarius).

DISTRIBUTION. The type locality only (Map: 9).

DESCRIPTION. MALE. Measurements: PL 2.6, PW 3.0, AW 1.6, OL 3.6, OW 2.5. Eye diameters: AME 0.20, ALE 0.10, PME 0.21, PLE 0.25. Eye interdistances: AMEAME 0.14, AME-PME 0.03, ALE-PLE 0.27. Leg and pedipalp measurements: Pedipalp 3.27 (0.90, 0.58, 0.75, -, 1.04); Leg I 10.7 (3.2, 1.2, 2.9, 2.4, 1.0); Leg II 13.5 (4.3, 1.3, 3.8, 2.9, 1.2); Leg III $12.4(4.5,1.2,3.2,2.5,1.0)$; Leg IV is absent. Leg formula: 231. Spination [leg IV is absent]: pedipalp Fm: 030, Pt 000, Tb 1200, Tr 2200; Fm I 230, II 030, III 030; Pt I-III 000; Tb I-II 0008, III 0000; Mt I-II 0006, III 0000. Chelicerae with 3 anterior and 2 posterior teeth; chelicerae with 1 bristle close to the retromargin of fang base. Coloration in ethanol (Figs 15-16). Body yellowish brown, with a faint pattern. Prosoma dorsally with 2 serrated dark longitudinal bands and wide dark marginal bands, fovea is marked with dark patch. Sternum yellowish brown, with dark margin, gnathocoxae, labium and chelicerae darker. Legs with indistinct banded pattern and small spine patches. Opisthosoma dorsally with irregularly shaped dark patches in its anterior half and a wide light patch in its posterior half; ventrally pale yellowish brown, with epiandrium sclerotised and dark anterior margin in front of spinnerets. Palp as characterised in the diagnosis (Figs 12-14): palpal tibia slightly wider than long, only with dorsal branch of RTA barely extending beyond distal tibia; embolus slightly curved, with a moderately broad proximal and narrow distal part (prolateral view), its tip indented; conductor originates from the tegulum at 12-o'clock-position, stout; median apophysis originates almost centrally from the tegulum, with two apices, one distad and another almost ventrad.

\section{FEMALE. Unknown.}

\section{Sparassidae}

\section{Heteropoda tetrica Thorell, 1897}

MATERIAL. VIETNAM: 1 ( (ZMMU), Dien Bien Prov., Muong Nhe Distr., Sin Thau Commune (22 $\left.21^{\prime} 54^{\prime \prime} \mathrm{N}, 102^{\circ} 14^{\prime} 15^{\prime \prime} \mathrm{E}\right)$ [1], $800 \mathrm{~m}$ a.s.1., June 2014, A.V. Abramov; $2 \mathrm{O}^{7} \mathrm{O}^{7}, 3$ 우 (MMUE, G7565.6), Ha Tinh Prov., Huong Son Distr., Son Kim Commune, c. $10 \mathrm{~km} \mathrm{~S}$ of Nuoc Sot Vil. (18 $\left.22^{\prime} \mathrm{N}, 105^{\circ} 13^{\prime} \mathrm{E}\right)$ [9], $200 \mathrm{~m}$ a.s.1., $11-$ 26.04.2000, A.V. Abramov; 2 우 (ZMMU), Ha Tinh Prov., Cam Xuyen Distr., Ke Go Nat. Res., nr. Mui Tru Station $\left(18^{\circ} 06^{\prime} 30^{\prime \prime} \mathrm{N}\right.$, $106^{\circ} 01^{\prime} 01^{\prime \prime}$ E) [11], $40 \mathrm{~m}$ a.s.1., 7-14.04.2015 A.V. Abramov; $1 \mathrm{O}^{\prime}$, 8 우 (ZMMU), Kon Tum Prov., eastern part of Chu Mom Ray Nat. Park, nr. Ro Koi Station $\left(14^{\circ} 30^{\prime} 18^{\prime \prime} \mathrm{N}, 107^{\circ} 43^{\prime 2} 22^{\prime \prime} \mathrm{E}\right)$ [13], $700 \mathrm{~m}$ a.s.1., 26.03-6.04.2015, A.V. Abramov; $1 \mathrm{O}^{7}$ (ZMMU), Dong Nai Province, Vinh Cuu Distr., Vinh Cuu Nat. Res., (= Ma Da Forest), TW Cuc Forest Station $\left(11^{\circ} 22^{\prime} 51^{\prime \prime} \mathrm{N}, 107^{\circ} 03^{\prime} 44^{\prime \prime} \mathrm{E}\right)$ [18], c. $75 \mathrm{~m}$ a.s.l., January-February 2010, A.V. Abramov; 3 of (MMUE, G7565.5), Dong Nai Prov., Cat Tien Nat. Park [19], OctoberDecember 2011, A. Goncharov.

COMMENTS. Common Oriental species, known from southern China (Yunnan and Guanxi), south-eastward to Malaysia and Indonesia (Sumatra) [Eusemann, Jäger, 2009; WSC, 2015]; hitherto recorded from Vietnam (Cat Ba Island nr. Haifon, Phong Nha-Ke Bang Nat. Park in Quang Binh Prov., and Sac Ha Vil. in Cao Bang Prov.) by Eusemann \& Jäger [2009]. 


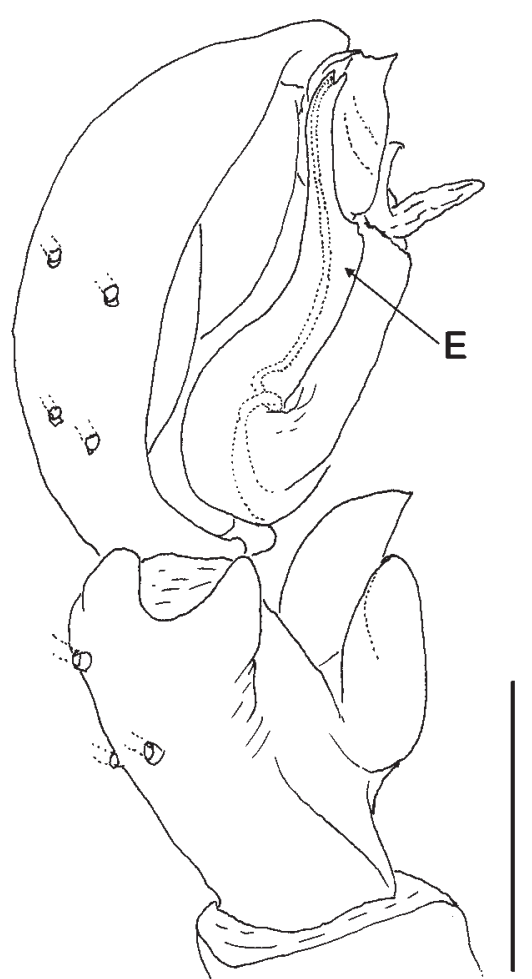

12

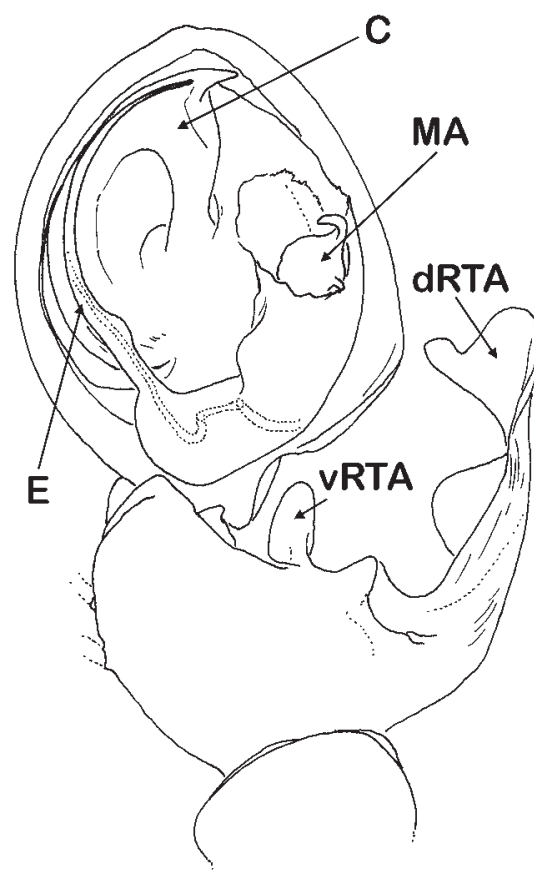

17

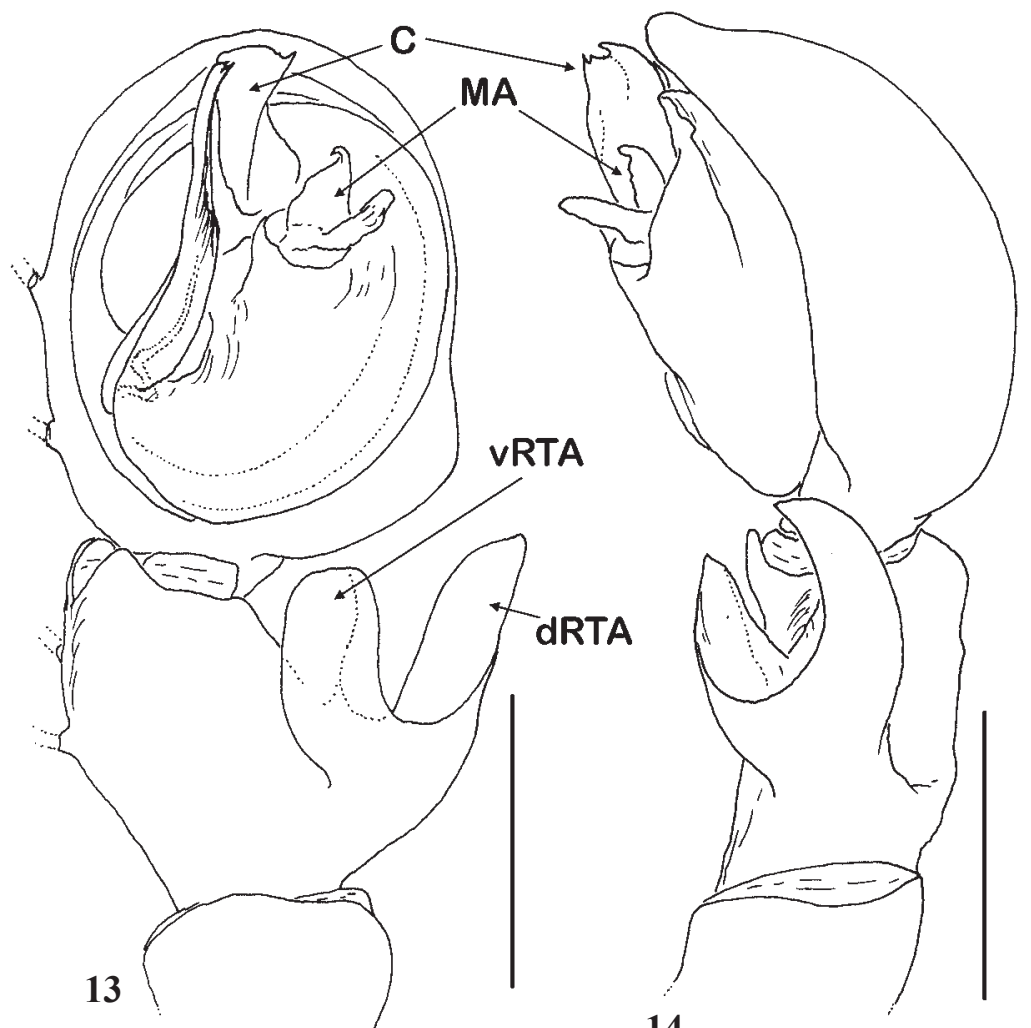

14

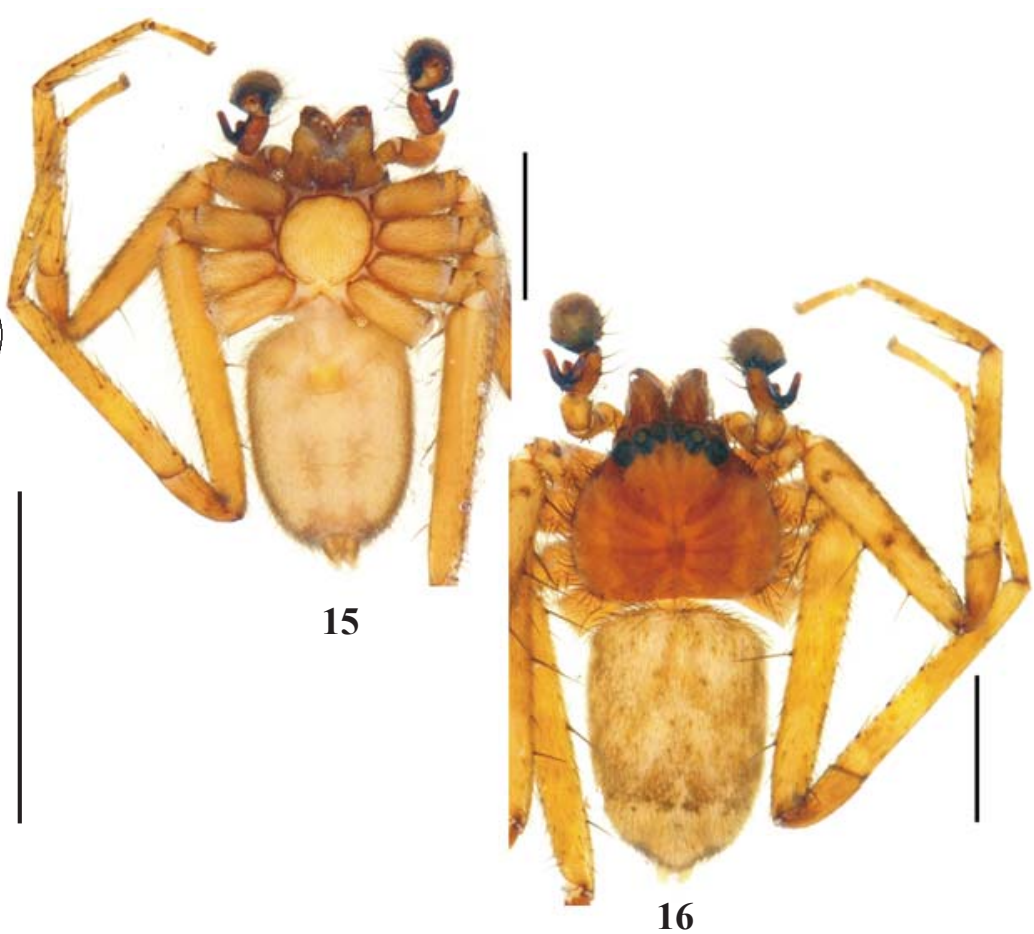

Figs 12-17. Copulatory organs and habitus of Selenops ab sp.n. ( $\sigma^{7}$ holotype; 12-16) and S. bursarius Karsch, 1879 from Japan (17), Selenopidae: 12 - male palp, prolateral view; 13, 17 - ditto, ventral view; 14 - ditto, retrolateral view; 15 - habitus, ventral view; 16 ditto, dorsal view. Scale bars: $(12-14,17) 0.5 \mathrm{~mm},(15-16) 2 \mathrm{~mm}$. Abbreviations: C — conductor; E — embolus; dRTA - dorsal branch of RTA; MA — median apophysis; vRTA — ventral branch of RTA.

Рис. 12-17. Копулятивные органы и габитус Selenops ab sp.n. (О' голотип; 12-16) и S. bursarius Karsch, 1879 из Японии (17), Selenopidae: 12 - пальпа самца, вид медиально; 13,17 - тоже, снизу; 14 - тоже, сзади-латерально; 15 - габитус, вид снизу; 16 тоже, сверху. Масштаб: (12-14, 17) 0,5 мм, (15-16) 2 мм. Сокращения: C — кондуктор; Е - эмболюс; dRTA - дорзальная ветвь RTA; MA - медиальный апофиз; vRTA — вентральная ветвь RTA. 
Heteropoda venatoria (Linnaeus, 1767)

MATERIAL, VIETNAM: $10^{7}$ (ZMMU), Ba Vi Distr. c. $50 \mathrm{~km}$ W of Hanoi, Ba Vi Nat. Park, nr. Tanh Linh Vil. $\left(21^{\circ} 05^{\prime} 49.6^{\prime \prime} \mathrm{N}\right.$, $105^{\circ} 24^{\prime} 07.3^{\prime \prime}$ E) [6], $100 \mathrm{~m}$ a.s.1., May 2013, A.V. Abramov; 1 क (MMUE, G7565.4), Ha Tinh Prov., Huong Son Distr., Son Kim Commune, c. $10 \mathrm{~km} \mathrm{~S}$ of Nuoc Sot Vil. (18 $\left.22^{\prime} \mathrm{N}, 105^{\circ} 13^{\prime} \mathrm{E}\right)$ [9], 200 m a.s.1., 11-26.04.2000, A.V. Abramov; $10^{7}$ (MMUE, G7565.2), Ha Tinh Prov., Cam Xuyen Distr., Ke Go Nat. Res., nr. Mui Tru Station $\left(18^{\circ} 06^{\prime} 30^{\prime \prime} \mathrm{N}, 106^{\circ} 01^{\prime} 01^{\prime \prime} \mathrm{E}\right)$ [11], $40 \mathrm{~m}$ a.s.1., 7-14.04.2015 A.V. Abramov; 1 ( (ZMMU), Kon Tum Prov., eastern part of Chu Mom

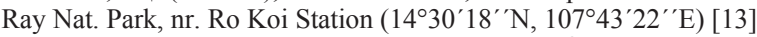
700 m a.s.1., 26.03-6.04.2015, A.V. Abramov; 1 क (ZMMU), Binh Phuoc Prov., c. 13 km NE of Bu Gia Map Vil., Bu Gia Map Nat. Park $\left(12^{\circ} 11^{\prime} 37^{\prime} \mathrm{N}, 107^{\circ} 12^{\prime} 21^{\prime \prime}\right.$ E) [16], c. $540 \mathrm{~m}$ a.s.1., January 2010, A.V. Abramov; 1 ( (ZMMU), Dong Nai Prov., Vinh Cuu Distr., Vinh Cuu

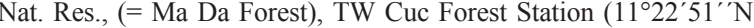
$107^{\circ} 03^{\prime} 44^{\prime \prime}$ E) [18], c. $75 \mathrm{~m}$ a.s.l., January-February 2010, A.V. Abramov; $1 O^{7}$ (MMUE, G7565.3), Dong Nai Prov., Cat Tien Nat. Park [19], October-December 2011, A. Goncharov; $1 \mathrm{O}^{\top}, 1$ q (ZMMU), Ba Ria - Vung Tau Prov., Central part of Con Son Island $\left(8^{\circ} 42^{\prime} \mathrm{N}\right.$, 106 $35^{\prime}$ 'E) [22], 5-300 m a.s.l., June 2010, A.V. Abramov.

COMMENTS. Widespread Pantropical species [WSC, 2015]; hitherto recorded from a number of localities in Vietnam by Simon [1886], Hogg [1922: sub Palystes ledlevi; see Ono et al., 2012] and Jäger [2014]: Saigon, Dran in Lam Dong Prov., Ky Thuong, Nam Cat Tien, Haifon, Cat Ba Island nr. Haifon, Koshinin, Ma Da in Dong Nai Prov., Vuih, Qua Phu in Thuan Hai Prov., and Buon Ya Wan in Daklak Prov.
Pseudopoda namkhan Jäger, Pathoumthong et Vedel, 2006

Pseudopoda namkhan Jäger, Pathoumthong et Vedel, 2006: 222, figs 20-28, 35-40 (D O'ㅇ).

P. houaphan Jäger, 2007: 55, figs 93-95 (D †). Syn.n.

MATERIAL. VIETNAM: 3 우 (ZMMU), Lao Cai Prov., Van Ban Distr., Nam Xay Commune (21 $\left.58^{\prime} 26^{\prime \prime} \mathrm{N}, 104^{\circ} 2^{\prime} 28^{\prime \prime} \mathrm{E}\right)$ [3], 900-1200 m a.s.1., 19.03-15.04.2005, A.V. Abramov.

COMMENTS. Oriental species known from northern Laos (Luangprabang, Houaphan), southern China (Yunnan) and northern Vietnam [WSC, 2015; present data]; first record for Vietnam (Map: 3).

The three studied females show quite a high variation in the shape (width/length ratio) of the epigynal field and lateral lobes. Having compared the specimens from the type locality (paratypes from S Yunnan, China) and from Houaphan in NE Laos (the holotype of $P$. houaphan), it has became clear that the conformation of the copulatory organs in the latter species falls within the currently understood strong intraspecific variation, and thus the species name $P$. houaphan is to be considered a junior synonym of $P$. namkhan. The variation of copulatory organs in this species is indeed high and similar to those described in other species distributed in this region: viz., Rhitymna plana Jäger, 2003 [Jäger, 2003, 2007]; Dendrolycosa robusta (Thorell, 1895) [Jäger, 2011]; and Ctenus simplex Thorell, 1897 [Jäger, 2012b].

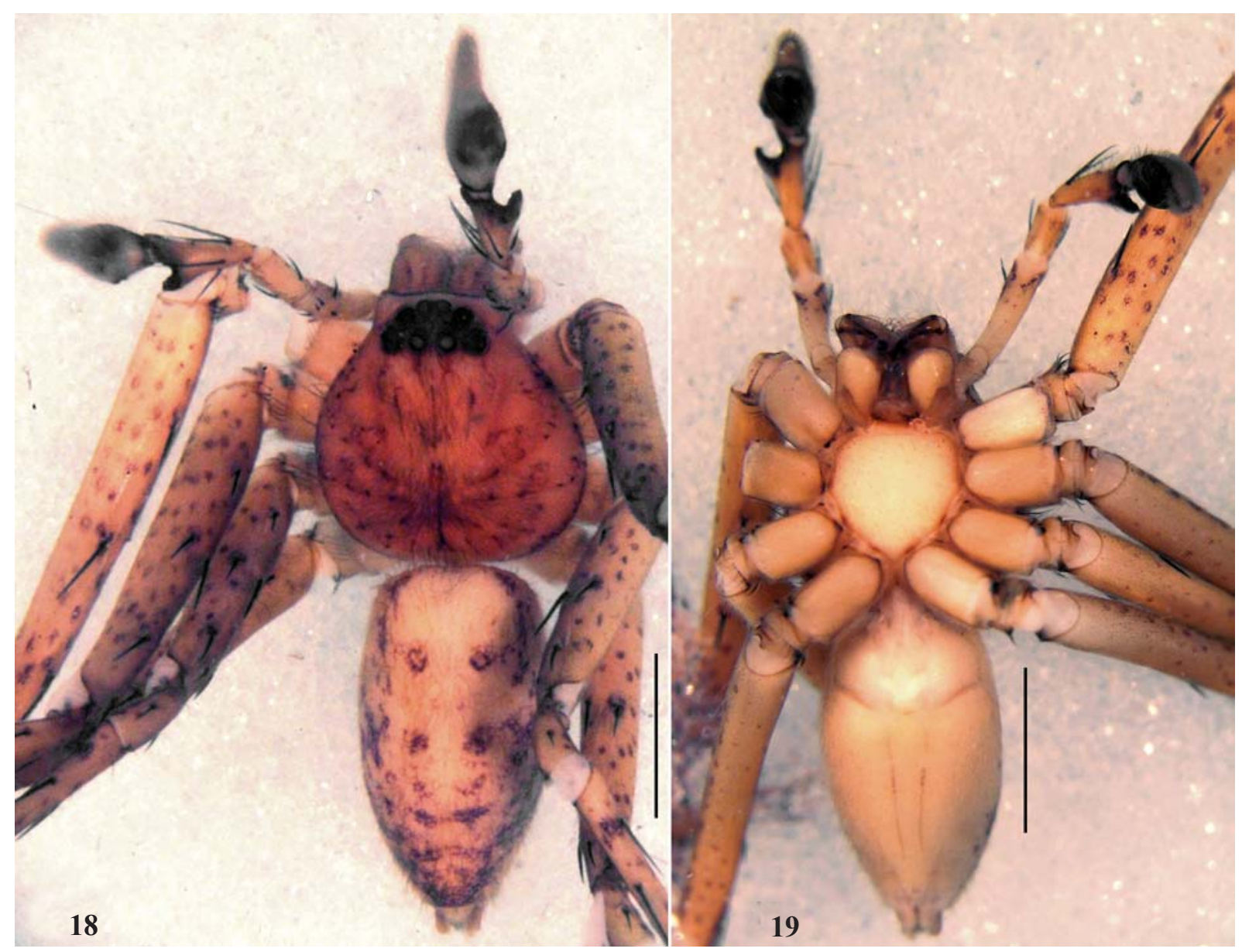

Figs 18-19. Habitus of Pseudopoda ohne sp.n. ( $0^{7}$ holotype), Sparassidae: 18 - dorsal view; 19 - ventral view. Scale bars: $2 \mathrm{~mm}$. Рис. 18-19. Габитус Pseudopoda ohne sp.n. (О голотип), Sparassidae: 18 - вид сверху; 19 - вид снизу. Масштаб: 2 мм. 


\section{Pseudopoda ohne Logunov et Jäger, sp.n.} Figs 18-23

TYPE. Holotype $\sigma^{7}$ (ZMMU) from Vietnam, Kon Tum Prov., Epart of Chu Mom Ray Nat. Park, near Ro Koi Station (1430'18' N, $\left.107^{\circ} 43^{\prime} 22^{\prime \prime} \mathrm{E}\right)$ [13], $700 \mathrm{~m}$ a.s.1., 26.09-06.04.2015, A.V. Abramov.

ETYMOLOGY. The specific epithet is derived from the German 'ohne' meaning 'without' and reflecting the fact that this species is characterized by the reduced conductor; a noun in apposition.

DIAGNOSIS. By the reduced conductor (Figs 20-23), the new species is similar to Pseudopoda wu Jäger, Li et Krehenwinkel, 2015, P. tji Jäger, 2015, P. pingu Jäger, 2015, $P$. bangaga Jäger, 2015, $P$. wamwo Jäger, 2015 and $P$. martinschuberti Jäger, 2015 (cf. Jäger [2015] and Jäger et al. [2015]). By the short embolus directed retrolaterad (Fig. 21), the embolic conformation is most similar to that of $P$. confusa Jäger, Pathoumthong et Vedel, 2006 (cf. Jäger et al. [2006]). From all the related species, P. ohne sp.n. can be distin- guished by the widened embolic base and the presence of disto-retrolateral tegular tooth.

DISTRIBUTION. The type locality only (Map: 13).

DESCRIPTION. MALE. Measurements. PL 3.5, PW 3.2, AW 1.6, OL 4.2, OW 2.3. Eye diameters: AME 0.18, ALE 0.27, PME 0.22, PLE 0.28. Eye interdistances: AMEAME 0.12, AME-ALE 0.05, PME-PME 0.19, PME-PLE 0.28, AME-PME 0.28, ALE-PLE 0.24, clypeus AME 0.30, clypeus ALE 0.27. Leg and pedipalps: pedipalp 5.8 (1.8, $0.8,1.3,-, 1.9)$; leg I $24.1(6.3,2.0,7.3,6.4,2.1)$; leg II 24.2 $(6.5,2.0,7.4,6.3,2.0)$; leg III $17.3(5.0,1.5,5.0,4.4,1.4)$; leg IV $21.8(6.2,1.5,6.0,6.4,1.7)$. Leg formula. 2143. Spination: pedipalp Fm: 131, Pt 010, Tb 2111; Fm I-III 323, IV 322; Pt I-III 101, IV 101/001; Tb I 2226, II-IV 2126; Mt I-II 1014, III 2025, IV 3037. Chelicerae with 3 anterior, 4 posterior teeth and ca. 30 denticles in a patch and a short row; chelicerae with one bristle close to the retromargin of fang base. Coloration in ethanol (Figs 18-19).

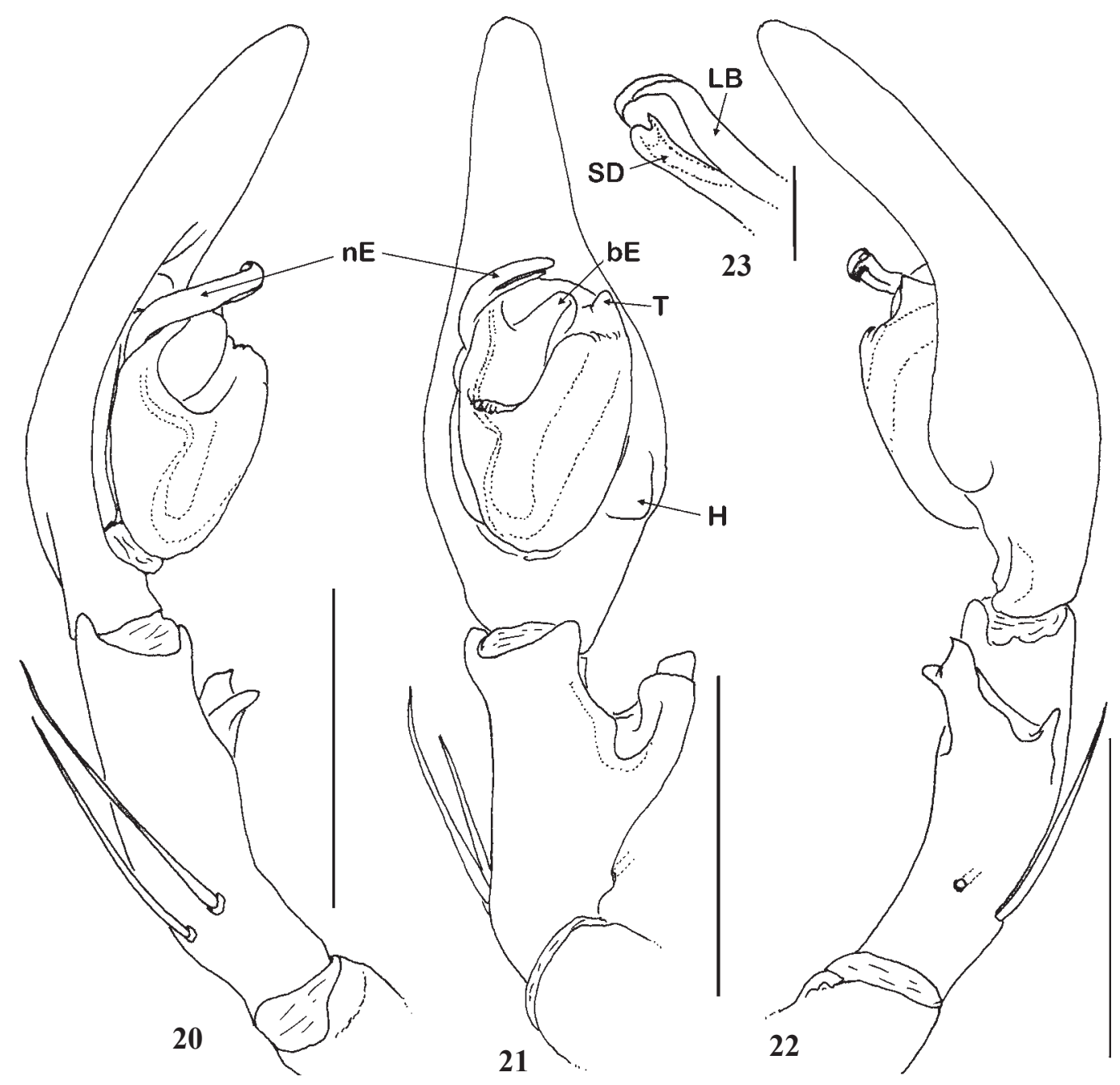

Figs 20-23. Male palp of the holotype of Pseudopoda ohne sp.n., Sparassidae: 20 - prolateral view; 21- ventral view; 22 - retrolateral view; 23 - embolic tip, retrolateral view. Scale bars: (20-22) $1 \mathrm{~mm},(23) 0.1 \mathrm{~mm}$. Abbreviations: bE - basal embolic apophysis; H - hump on retrolateral cymbial bulge; LB — larger branch of embolus; $\mathrm{nE}$ — narrow apical part of embolus; $\mathrm{SD}$ - sperm duct; $\mathrm{T}$ - disto-retrolateral tegular tooth.

Рис. 20-23. Пальпа самца, голотипа Pseudopoda ohne sp.n., Sparassidae: 20 — вид медиально; 21 - вид снизу; 22 - вид сзадилатерально; 23 - вершина эмболюса, вид сзади-латерально. Масштаб: (20-22) 1 мм, (23) 0,1 мм. Сокращения: bЕ - базальный апофиз эмболюса; H - выступ на задне-латеральном бугре цимбиума; LB - более крупная ветвь эмболюса; $\mathrm{nE}$ - более узкая, апикальная часть эмболюса; SD - семенной каналец; T — дистально-задне-латеральный зуб тегулума. 
Prosoma and opisthosoma yellowish brown, with a brown pattern. Dorsal shield of prosoma with striae marked with dots, additional dark setae and dark margin. Sternum, labium, gnathocoxae and ventral coxae pale yellowish brown, without a pattern. Each chelicera frontally with 3 longitudinal stripes. Legs dotted and with spine patches. Opisthosoma dorsally with muscle sigilla marked, with chevrons in its posterior half; laterally with an irregular dark pattern; ventrally pale yellowish brown, without a pattern. Palp as characterised in the diagnosis (Figs 20-23): cymbium with long, roughly triangular tip and a small hump on the retrolateral bulge; RTA originates from Tb medially to distally, with three short apices, none of which distally extends beyond the distal end of $\mathrm{Tb}$; embolus distally furcate, originating from the tegulum at 9:30 o'clock-position, with a distinct basal apophysis running parallel to a narrow apical part of the embolus as seen in ventral view; the sperm-duct carrying part of the embolus is situated proximo-dorsally of its larger branch, and with an indented tip.

FEMALE. Unknown.

\section{Thelcticopis buu Logunov et Jäger, sp.n.}

Figs 24-28.

TYPE. Holotype $O^{7}$ (ZMMU) from Vietnam, Ba Ria-Vung Tan

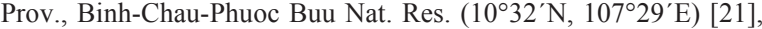
$50 \mathrm{~m}$ a.s.l., June 2007, A.V. Abramov.

ETYMOLOGY. The specific epithet is a noun in apposition taken from the type locality, Binh-Chau-Phuoc Buu Nat. Res. in Vietnam.

DIAGNOSIS. By a small body size and the conformation of the male palp (Figs 24-26), the new species is similar to Thelcticopis zhengi Liu, Li et Jäger, 2010 from China [cf. Liu et al., 2010], but can be distinguished from it by the following characters: (1) the embolus is freely visible in ventral view (covered by the tegular apophysis in $T$. zhengi); (2) RTA is simple, with one apex (with two apexes in T. zhengi); (3) the median apophysis is directed distad in ventral view (retrolaterad in T. zhengi). There are two species described from the Philippines that display a similar palpal conformation [see Barrion, Litsinger, 1995]: T. kianganensis Barrion et Litsinger, 1995 having the embolus freely visible and of the similar

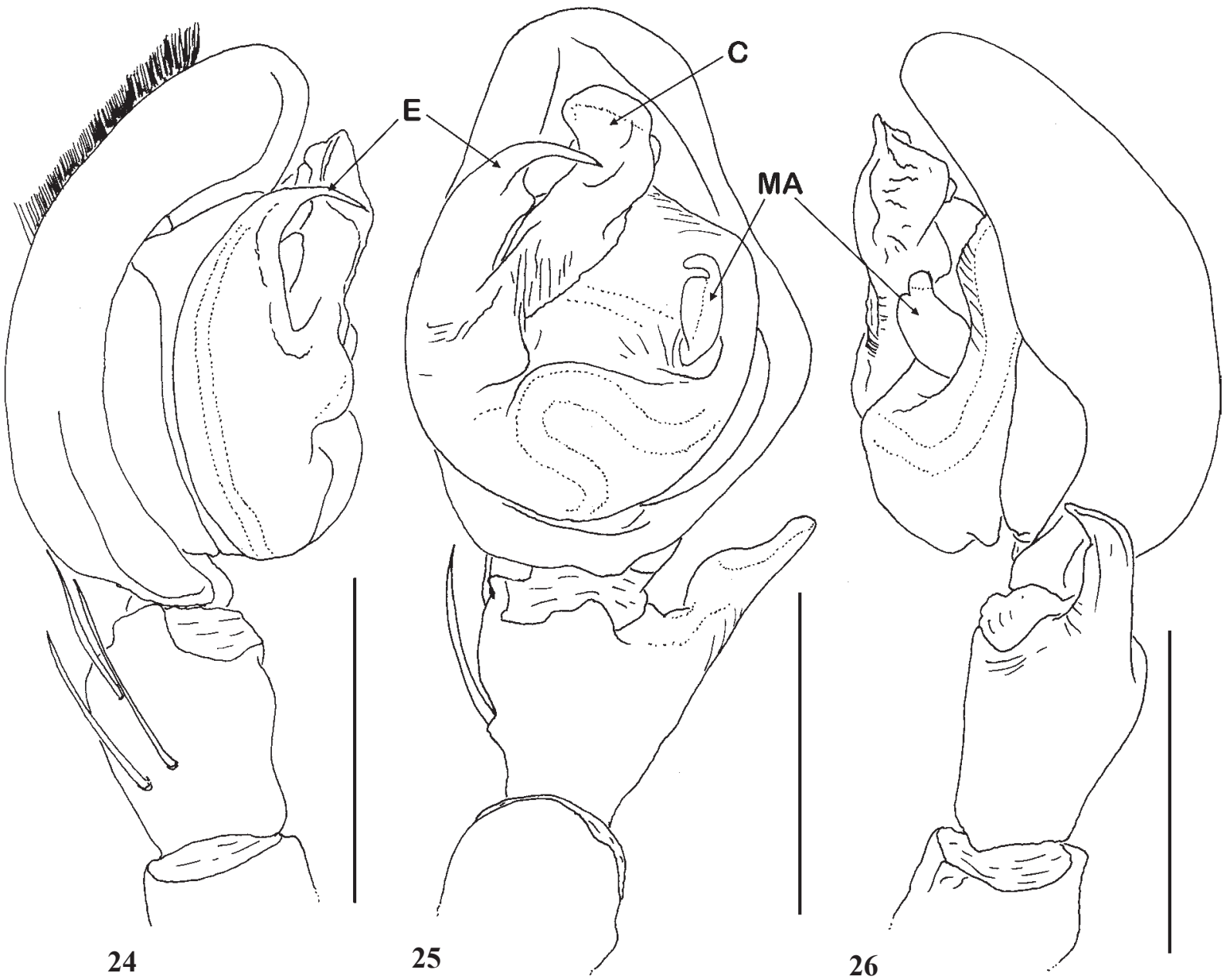

Figs 24-26. Copulatory organs of Thelcticopis buu sp.n. ( $\sigma^{7}$ holotype), Sparassidae: 24 - male palp, prolateral view; 25 - ditto, ventral view; 26 - ditto, retrolateral view. Scale bars: $1 \mathrm{~mm}$. Abbreviations: E - embolus; MA — median apophysis; C - conductor.

Рис. 24-26. Копулятивные органы Thelcticopis buи sp.n. (О' голотип), Sparassidae: 24 — пальпа самца, вид медиально; 25 - тоже, снизу; 26 - тоже, задне-латерально. Масштаб: 1 мм. Сокращения: Е — эмболюс; МА — медиальный апофиз; С — кондуктор. 
length as that in T. buu sp.n., but with the RTA complex (i.e., with three apexes); and $T$. simplerta Barrion et Litsinger, 1995 with the RTA simple (i.e., with one apex), but with the long embolus, originating at six o'clock-position and running more than a semicircle.

DISTRIBUTION. The type locality only (Map: 21).

DESCRIPTION. MALE. Measurements. PL 5.1, PW 4.2, AW 2.4, OL 5.5, OW 3.5. Eye diameters: AME 0.27, ALE 0.20, PME 0.20, PLE 0.21. Eye interdistances: AMEAME 0.21, AME-ALE 0.27, PME-PME 0.48, PME-PLE 0.54, AME-PME 0.22, ALE-PLE 0.26, clypeus AME 0.23 , clypeus ALE 0.17. Leg and pedipalps: pedipalp 5.1 (1.8, 0.7, $0.8,-, 1.8)$; leg I $17.3(4.7,2.5,5.0,4.0,1.1)$; leg II 16.9 (4.8, $2.5,4.6,3.9,1.1)$; leg III $13.4(4.0,2.0,3.4,3.0,1.0)$; leg IV $17.3(5.0,1.9,4.5,4.6,1.3)$. Leg formula (14)23. Spination: pedipalp Fm: 131, Pt 101, Tb 2001; Fm I-II 323, III 322, IV 321; Pt I-IV 000; Tb I-II 202 10, III-IV 2026; Mt I-II 2022 III 3033, IV 3035. Chelicerae with 3 anterior and 5 posterior teeth; chelicerae with 1 bristle close to the retromargin of fang base. Coloration in ethanol (Figs 27-28). Yellowish to reddish brown. Prosoma dorsally reddish brown, with fovea in its posterior quarter, short and few dark lines in head part accompanied with bristles. Sternum yellowish brown, coxae ventrally pale yellowish brown. Gnathocoxae and labium deep yellowish brown, with white distal lips. Chelicerae frontally with 3 longitudinal dark lines. Legs yellowish brown, without a pattern. Opisthosoma dorsally with a light heart region and chevrons in its posterior half; laterally with irregular small patches; ventrally pale yellowish brown, slightly stronger sclerotised and darker in front of the epigastric furrow. Palp as characterised in the diagnosis (Figs 24-26): RTA originates from tibia distally, simple, i.e. with one apex which appears blunt in ventral view and slightly curved in retrolateral view; cymbium dorsally with a patch of setae in its distal half; embolus originates from the tegulum from 9 to
9.30 o'clock-position, proximal part broad, distal part narrow, curved and pointed; conductor originates from the tegulum close to the embolic base, narrower proximally than distally; median apophysis with a distinct prolateral incision seen in ventral view; sperm duct wide and S-shaped in the proximal side of tegulum, narrow and only slightly curved in the prolateral side of tegulum.

FEMALE. Unknown.

\section{Thomisidae}

Lysiteles conicus Tang, Yin, Peng, Ubick et Griswold, 2007

MATERIAL. VIETNAM: 1 (ZMMU), Ba Ria - Vung Tau

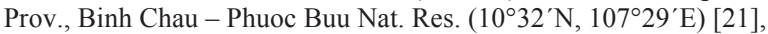
$50 \mathrm{~m}$ a.s.1., June 2007, A.V. Abramov.

COMMENTS. To date, the species has been known from the type locality only: China (Yunnan) [Tang et al., 2007]; first record for Vietnam (Map: 21).

\section{Lysiteles dentatus Tang, Yin, Peng, Ubick et Gris-} wold, 2007

MATERIAL. VIETNAM: $10^{7}$ (ZMMU), Ba Ria - Vung Tau Prov., Binh Chau - Phuoc Buu Nat. Res. $\left(10^{\circ} 32^{\prime} N, 17^{\circ} 29^{\prime} E\right)$ [21], $50 \mathrm{~m}$ a.s.1., June 2007, A.V. Abramov.

COMMENTS. To date, the species has been known from the type locality only: China (Yunnan) [Tang et al., 2007]; first record for Vietnam (Map: 21).

\section{Lysiteles punctiger Ono, 2001}

MATERIAL. VIETNAM: $50^{\top} \sigma^{7}$ (ZMMU), Ba Ria - Vung Tau

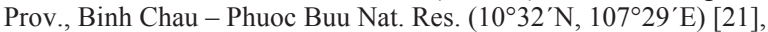
$50 \mathrm{~m}$ a.s.l., June 2007, A.V. Abramov.

COMMENTS. To date, the species has been known from China (Yunnan) and Bhutan [Tang et al., 2008; WSC, 2015]; first record for Vietnam (Map: 21).
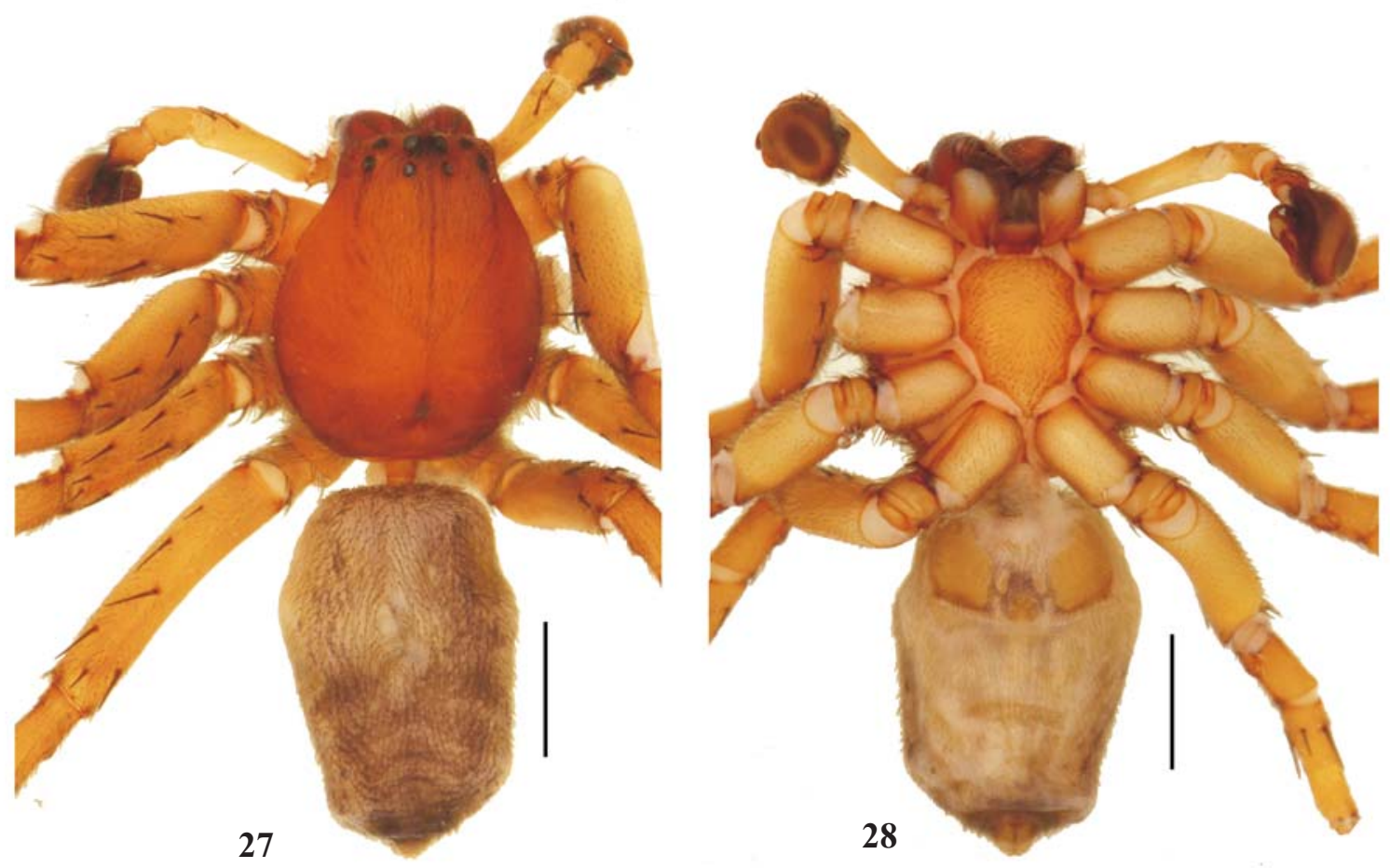

Figs 27-28. Habitus of Thelcticopis buu sp.n. (O' holotype), Sparassidae: 27 - dorsal view; 28 - ditto, ventral view. Scale bars: $2 \mathrm{~mm}$. Рис. 27-28. Габитус Thelcticopis buи sp.n. (О' голотип), Sparassidae: $27-$ вид сверху; $28-$ вид снизу. Масштаб: 2 мм. 
The identification of these males has been done on the basis of Tang et al. [2008: figs 14a-j]. Yet, the studied males from Vietnam differ from those described and illustrated in the latter work in their body coloration, viz. in having the yellow carapaces with dark brown clypeus and margins (completely brown in the Chinese specimens).

Lysiteles torsivus Zhang, Zhu et Tso, 2006

MATERIAL. VIETNAM: $1 \sigma^{7}$ (ZMMU), Ba Ria - Vung Tau

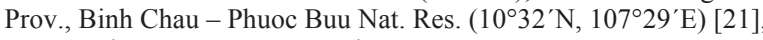
$50 \mathrm{~m}$ a.s.1., June 2007, A.V. Abramov.

COMMENTS. To date, the species has been known from China (Yunnan) and Taiwan [Tang et al., 2008; WSC, 2015]; first record for Vietnam (Map: 21)

\section{Lysiteles vietnamensis Logunov et Jäger, sp.n.} Figs 29-32.

TYPES. Holotype $\sigma^{7}$ (ZMMU) from Vietanm, Ba Ria - Vung Tau Prov., Binh Chau - Phuoc Buu Nat. Res. $\left(10^{\circ} 32^{\prime} \mathrm{N}, 107^{\circ} 29^{\prime} \mathrm{E}\right)$ [21], $50 \mathrm{~m}$ a.s.1., June 2007, A.V. Abramov. - Paratypes: 4 우 (ZMMU), together with the holotype.

ETYMOLOGY. Named after the country of origin, Vietnam; adjective.

DIAGNOSIS. From all the known Lysiteles species (see WSC [2015] for a list of species and references), L. vietnamensis sp.n. differs by the following characters: the flat and round tegulum, the shape of the embolus, VTA and RTA (Figs 29-30) in the male, and the presence and shape of the median septum of the epigyne and the unique conformation of the spermathecae with insemination ducts making almost a complete turn around the axis (Figs 31-32) in the female.

DISTRIBUTION. The type locality only (Map: 21).

DESCRIPTION. MALE (the holotype). Measurements. Carapace: 1.18 long, 1.15 wide. Abdomen: 1.35 long, 1.18 wide. Clypeus 0.17 long, chelicera 0.31 long. Eye sizes and interdistances: MOA-WA 0.24, MOA-WP 0.31, MOA-L 0.26, AME 0.07, ALE 0.08, PME 0.05, PLE 0.06, AMEAME 0.13, AME-ALE 0.11, PME-PME 0.21, PME-PLE 0.16 . Length of leg segments: I: $1.85+0.60+1.45+1.40+$ 1.00 ; II: $1.80+0.60+1.45+1.35+0.95$; III: $0.85+0.38+$ $0.60+0.50+0.38 ;$ IV: $0.83+0.33+0.58+0.55+0.40$. Spination of leg I: Fm d 1-1-1-1-1, pr 1-1-1-1, rt 1-1; Pt pr and rt 0-1-0; Tb d 0-1, pr 1-1, rt 0-1, v 2-2; Mt pr and rt 1-1$1 \mathrm{ap}, \mathrm{v} 2-2$. Coloration in alcohol. Carapace light yellow, with two wide, longitudinal, light brown stripes behind PLEs. Clypeus, labium, maxillae and chelicerae light yellow. Abdomen light yellow, without dorsal patten and ventrally and on sides with large brown patches near the spinnerets. Booklung covers yellow; spinnerets brownish yellow. Legs I and II light yellow, with light brown wide rings. Legs III and IV entirely light yellow. Palps light yellow. Palpal structure as in Figs 29-30; RTA long, with a large sharp tooth at its apex; VTA long and narrow; tegulum flat and round; embolus originates at about seven o'clock-position and terminates at about two o'clock-position.
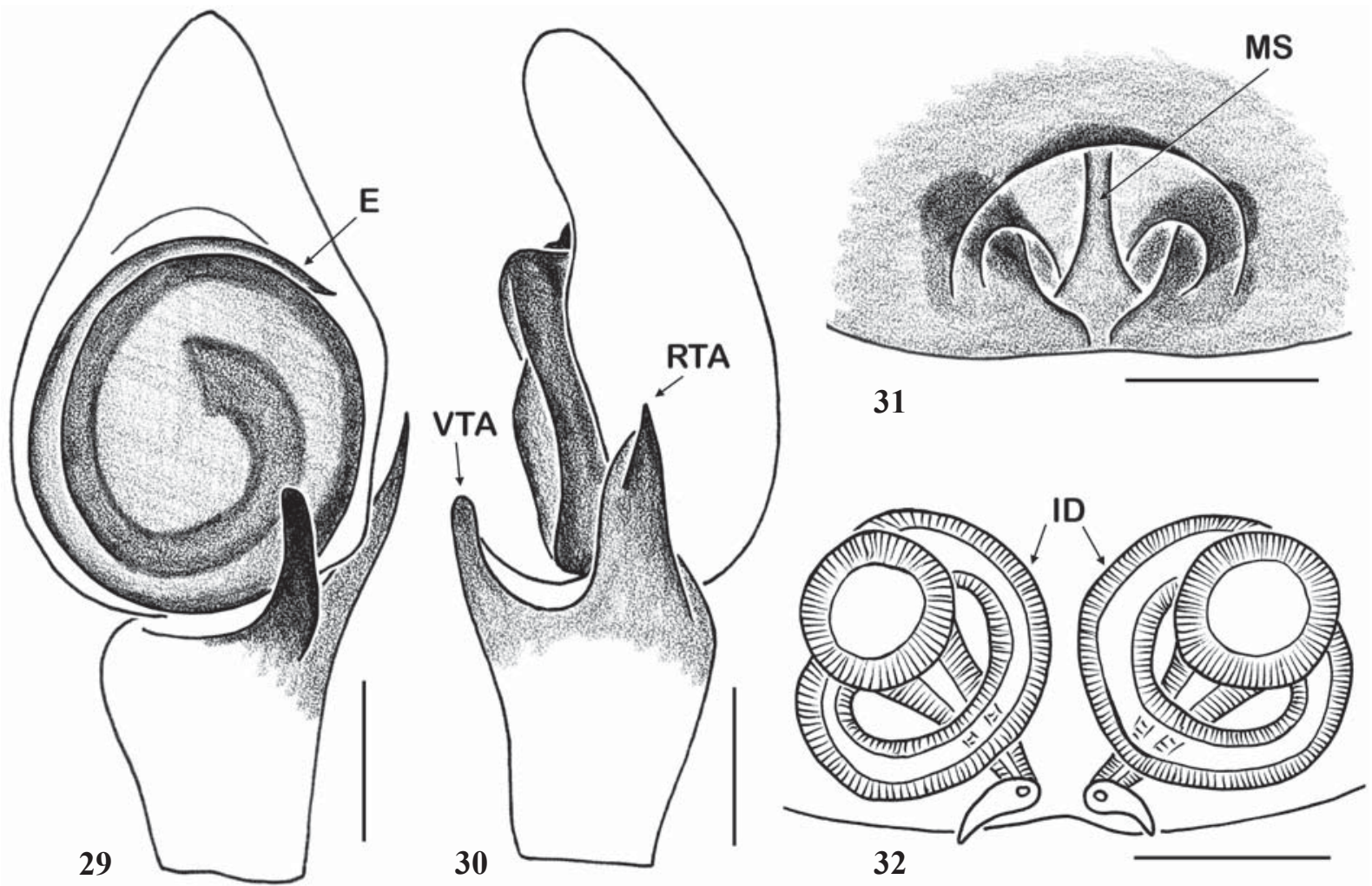

Figs 29-32. Copulatory organs of Lysiteles vietnamensis sp.n. ( $\sigma^{7}$ holotype, 9 paratype), Thomisidae: 29 — male palp, ventral view; 30 — ditto, retrolateral view; 31 - epigyne, ventral view; 32 - spermathecae, dorsal view. Scale bars: 0.1 mm. Abbreviations: E - embolus; ID insemination ducts; MS — median septum; RTA — retrolateral tibial apophysis; VTA — ventral tibial apophysis.

Рис. 29-32. Копулятивные органы Lysiteles vietnamensis sp.n. ( ( голотип, о паратип), Тhотіsidae: 29 - пальпа самца, вид снизу; 30 - тоже, задне-латерально; 31 - эпигина, вид снизу; 32 - сперматека, вид сверху. Масштаб: 0,1 мм. Сокращения: Е - эмболюс; ID - копулятивные каналы; MS - медиальный септум; RTA - задне-латеральный голенный отросток; VTA - вентральный голенный отросток. 
FEMALE (the illustrated + ). Measurements. Carapace: 1.45 long, 1.33 wide. Abdomen: 2.35 long, 2.13 wide. Clypeus 0.21 long, chelicera 0.65 long. Eye sizes and interdistances: MOA-WA 0.31, MOA-WP 0.35, MOA-L 0.34, AME 0.09, ALE 0.16, PME 0.04, PLE 0.13, AME-AME 0.15, AME-ALE 0.14, PME-PME 0.24, PME-PLE 0.29. Length of leg segments: I: $1.38+0.55+1.18+0.90+0.65$ II: $1.48+0.55+1.25+1.03+0.65$; III: $1.00+0.38+0.73$ $+0.60+0.40 ;$ IV: $1.05+0.40+0.85+0.64+0.38$ Spination of leg I: Fm d and pr 0-1-1; Pt rt 0-1-0; Tb d and pr $0-1-1$, rt 1-1-1, v 2-2; Mt pr and rt 1-1, v 2-2-2ap. Coloration in alcohol as in the male, but without light brown rings on legs I and II and large brown patches ventrally near the spinnerets; abdomen with two wide longitudinal, interrupted brownish stripes on dorsum and narrower stripes on abdominal sides. Epigyne and spermathecae as in Figs 31-32: epigyne with a narrow median septum and wide anterior rim; copulatory openings separated and wide; insemination ducts make almost a complete turn around the axis; receptacles enema-shaped.

\section{Xysticus croceus Fox, 1937}

MATERIAL. VIETNAM: $1 \sigma^{7}$ (MMUE, G7565.20), Lao Cai Prov., c. $6 \mathrm{~km} \mathrm{~W}$ of Sa Pa, north slope of Fansipan Mt. area, Hoang Lien Nat. Park, nr. Tram Ton Station $\left(22^{\circ} 21^{\prime} \mathrm{N}, 1^{\circ} 3^{\circ} 46^{\prime} \mathrm{E}\right)$ [2], 1930-2000 m a.s.1., May 2008, A.V. Abramov; $60^{7} \sigma^{7}, 1$ (ZMMU), Lao Cai Prov., Van Ban Distr., Nam Xay Commune $\left(21^{\circ} 58^{\prime} 26^{\prime \prime} \mathrm{N}\right.$, $104^{\circ} 02^{\prime} 28^{\prime \prime}$ E) [3], 900-1200 m a.s.1., 19.03-15.04.2005, A.V. Abramov.

COMMENTS. Common east Asian species, known from Nepal and Bhutan in the west, throughout China to Japan in the east, south-eastward to Taiwan [WSC, 2015]; first record for Vietnam (Map: 2,3).

\section{Salticidae}

Burmattus pococki (Thorell, 1895)

MATERIAL. VIETNAM: 10 , 1 9 (ZMMU), Ha Tinh Prov., Cam Xuyen Distr., Ke Go Nat. Res., nr. Mui Tru Station $\left(18^{\circ} 06^{\prime} 30^{\prime \prime} \mathrm{N}, 106^{\circ} 01^{\prime} 01^{\prime \prime} \mathrm{E}\right)$ [11], $40 \mathrm{~m}$ a.s.1., 7-14.04.2015 A.V. Abramov.

COMMENTS. Oriental species, distributed from Bhutan and Myanmar in the west, throughout southern China to Vietnam and Japan in the east [WSC, 2015; Metzner, 2015]; hitherto recorded from a number of localities in Vietnam by Żabka [1985: sub Plexippus p.], Peng, Li [2003] and Pham et al. [2004]: Hanoi (incl. Xuan Dinh, Thu Le and Bac Thao), Gao Bao and Viet Lann villages in Ha Jiang Prov., Phu Que in Nghe An Prov., Cuc Phuong in Ninh Binh Prov., Thuong Linh (nr. Phu Ly), Tab Linch Vil. in Son Tay Prov., and Bac Thai.

\section{Carrhotus sannio (Thorell, 1877)}

MATERIAL. VIETNAM: $10^{7}$ (ZMMU), Ha Tinh Prov., Huong Son Distr. Son Kim Commune, c. $10 \mathrm{~km} \mathrm{~S}$ of Nuoc Sot Vil $\left(18^{\circ} 22^{\prime} \mathrm{N}, 105^{\circ} 13^{\prime} \mathrm{E}\right)$ [9], $200 \mathrm{~m}$ a.s.l., 11-26.04.2000, A.V. Abramov.

COMMENTS. Widespread Oriental species, distributed from Afghanistan and India in the west to Malaysia and the Philippines in the east [WSC, 2015; Metzner, 2015]; hitherto recorded from a number of localities in Vietnam by Żabka [1985], Peng, Li [2003] and Pham et al. [2004]: Hanoi, c. 120 km NW of Vinh in Nghe An Prov., Chine, Cuc Phuong in Ninh Binh Prov., Thanh Ha in Hoa Binh Prov., Coc Xan in Lao Cai Prov., Quang Ninh, Vo Nhai, Bac Thai, Tab Linch and Tan Linh villages in Son Tay Prov., Viet Lann Vil. in Ha Jiang Prov., Quang Hoa in Cao Bang Prov., Sac Ha Vil. in Cao Bang Prov., and Vinh Phu.
Epeus glorius Żabka, 1985

MATERIAL. VIETNAM: $5 \sigma^{7} \sigma^{7}$ (ZMMU), Ha Tinh Prov., Huong Son Distr., Son Kim Commune, c. $10 \mathrm{~km}$ S of Nuoc Sot Vil. $\left(18^{\circ} 22^{\prime} \mathrm{N}, 105^{\circ} 13^{\prime} \mathrm{E}\right)$ [9], $200 \mathrm{~m}$ a.s.l., 11-26.04.2000, A.V. Abramov.

COMMENTS. Poorly documented Oriental species, recorded from China (Guangxi), Malaysia and Vietnam [Song et al., 1999; WSC, 2015; Metzner, 2015]; in Vietnam, it has been hitherto known from the type locality only: Phu Que, c. $80 \mathrm{~km}$ NW of Vinh, Nghe An Prov. [Żabka, 1985], also listed by Pham et al. [2004].

Foliabitus scutigerus (Żabka, 1985)

MATERIAL. VIETNAM: $20^{\top} 0^{7}$ (ZMMU), Lao Cai Prov., Van

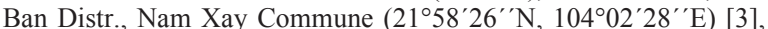
900-1200 m a.s.1., 19.03-15.04.2005, A.V. Abramov.

COMMENTS. To date, this species has been known from the male holotype and from the type locality only: Cuc Phuong in Ninh Binh Prov. [Żabka, 1985: sub Laufeia s.], also listed by Pham et al. [2004: sub Laufeia s.].

Hasarius adansoni (Audouin, 1826)

MATERIAL. VIETNAM: $1 \sigma^{7}$ (MMUE, G7565.23), Son La Prov., Phu Yen Distr., Suoi To Commune, nr. Suoi Khang Vil., c. 10 $\mathrm{km}$ NW of Phu Yen Town $\left(21^{\circ} 20^{\prime} 13.2^{\prime \prime} \mathrm{N}, 104^{\circ} 36^{\prime} 29.7^{\prime \prime} \mathrm{E}\right)$ [4], 1100 m a.s.1., May 2013, A.V. Abramov; 2 우 (MMUE, G7565.24), Ba Vi Distr., c. $50 \mathrm{~km} \mathrm{~W}$ of Hanoi, Ba Vi Nat. Park, nr. Ba Vi Resort $\left(21^{\circ} 04^{\prime} 57.9^{\prime \prime} \mathrm{N}, 105^{\circ} 22^{\prime} 54.1^{\prime \prime} \mathrm{E}\right)$ [6], 35-400 m a.s.1., May 2013, A.V. Abramov; $20^{7} 0^{7}$ (PSU), Binh Thuan Prov., c. $10 \mathrm{~km} \mathrm{E}$ of Phan Thiet $\left(10^{\circ} 56^{\prime} \mathrm{N}, 108^{\circ} 11^{\prime} \mathrm{E}\right)$ [20], on sea shore, 15.03.2001, T. Tuneva.

COMMENTS. Cosmopolitan species [WSC, 2015]; hitherto recorded from a number of localities in Vietnam by Hogg [1922: sub. Tachyscarthmus annamensis], Żabka [1985], Peng, Li [2003], Pham et al. [2004], and Pham [2012]: Hanoi, Chine $-80 \mathrm{~km}$ SW of Hanoi, Dran in Lam Dong Prov., Quang Hoa in Cao Bang Prov., Quang Ninh, and Long Son Prov.

Laufeia squamata (Żabka, 1985), comb.n. Figs 33-39.

MATERIAL. VIETNAM: $10^{\top}, 2$ 우 (ZMMU), Ha Tinh Prov., Huong Son Distr., Son Kim Commune, c. $10 \mathrm{~km} \mathrm{~S}$ of Nuoc Sot Vil. $\left(18^{\circ} 22^{\prime} \mathrm{N}, 105^{\circ} 13^{\prime} \mathrm{E}\right)$ [9], $200 \mathrm{~m}$ a.s.1., 11-26.04.2000, A.V. Abramov.

DIAGNOSIS. This species is closest to the type species of Laufeia - L. aenea Simon, 1889 known from the eastern Palaearctic Region (China, Korea, Japan; WSC [2015]) from which it can easily be distinguished by the conformation of the embolic division and the presence of the ventral tibial apophysis in the male (Figs 33-34), and by the sizes and proportions of the receptacles seen through the integument in the female (cf. Figs 37-38 and figs 84-89 in Bohdanowicz, Prószyński [1987]); surprisingly, the spermathecae of $L$. aenea has never been figured yet. The male of L. squamata is illustrated and described here for the first time.

COMMENTS. The discovery of the male of Lechia squamata allows us to resolve the taxonomic status of the monotypic genus Lechia Żabka, 1985. Both sexes (see Figs 33-39) possesses the main diagnostic characters of the genus Laufeia Simon, 1889 [see Simon, 1889; Ikeda, 1998; Zhang, Maddison, 2015]: viz., fissidenate retromarginal tooth (Fig. 39); leg formula I, IV, II, III in the male (as stated in Simon [1889], contra Ikeda [1998]) and IV, III, I, II in the female (differs from that in the female of $H$. aenea: IV, I, III, II [see Ikeda, 1998]); the large dorsal scutum in the male (Fig. 36); the tegulum with the well-developed proximal lobe; the embolic 
division of the male palp with two sclerites: the embolus and the terminal apophysis (exactly as the conformation of the embolic division in the type species, see Bohdanowicz, Prószyński [1987] and Ikeda [1998]); and the fossae (= epigynal windows) of the epigyne shallow and poorly marked. The unique feature of $L$. squamata is the well-developed ventral tibial apophysis in the male palp (Fig. 34) that is absent in the majority of Laufeia species; yet the marked basal bulges at the base of RTA (almost like ventral apophyses) present in L. aenea and L. sasakii Ikeda, 1998 from Japan [Ikeda, 1998: figs 5, 11; Zhang, Maddison, 2015: fig. 507].

The present assignment of Lechia squamata, the type species of Lechia, to the genus Laufeia leave no doubts that both generic names are to be synonymized.

DISTRIBUTION. To date, the species has been known from China (Hainan) and Vietnam (Hanoi and Viet Tri in Vinh Phu Prov., and Nuoc Sot Vil. in Ha Tinh Prov. [9]) only [Żabka, 1985; Song et al., 1999; Pham et al., 2004; present data].
DESCRIPTION. MALE. Measurements. Carapace 2.03 long, 1.43 wide and 0.93 high at PLE. Ocular area 1.03 long, 1.25 wide anteriorly and 1.00 wide posteriorly. Diameter of AME 0.38. Clypeus height 0.08, chelicera length 0.63. Abdomen 1.88 long, 1.25 wide. Length of leg segments: I: $1.10+$ $0.75+0.80+0.53+0.38 ;$ II: $0.90+0.50+0.55+0.45+0.33$; III: $0.88+0.43+0.53+0.50+0.33$; IV: $0.93+0.48+0.68$ $+0.58+0.33$. Leg spination. Leg I: Fm d 0-1-1-2; Tb pr 0-10, v 2-1-2ap; Mt v 2-2ap. Leg II: Fm d 0-1-3; Tb v 2-2-2ap; Mt v 2-2ap. Leg III: Fm d 0-1-1-2; Tb rt 1-0, v 1ap; Mt pr and rt 2ap. Leg IV: Fm d 0-1-1-2; Tb rt 1-0, v lap; Mt no spines. Coloration in alcohol. Carapace brown, with dark brown eye field and black around eyes; carapace covered with sparse long white hairs. Clypeus brown, with a marginal fringe of white hairs. Sternum brown-yellow. Maxillae, labium and chelicerae brown. Abdomen grey, without a colour pattern; dorsum with a large shiny brown scutum covering $3 / 4$ of its length. Book-lung covers and spinnerets yellow. Legs I and II: all segments dark brown, but metatarsi and tarsi yellow;

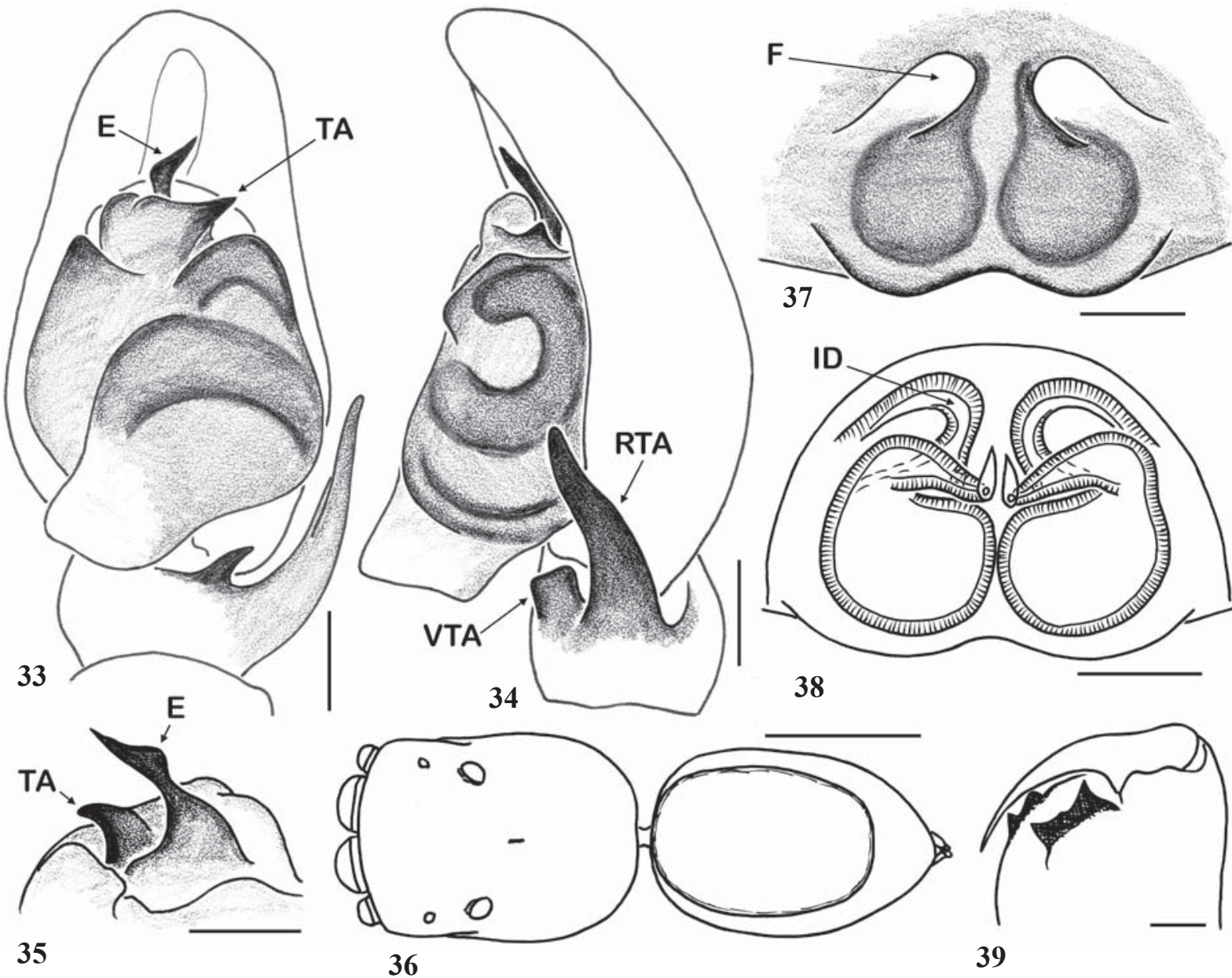

Figs 33-39. Copulatory organs and habitus of Laufeia squamata (Żabka, 1985), Salticidae, from Vietnam (Nuoc Sot Vil. in Ha Tinh Prov.; see Map: 9): 33 - male palp, ventral view; 34 - ditto, retrolateral view; 35 - embolic division, dorsal view; 36 - male habitus; 37 - epigyne, ventral view; 38 - spermathecae, dorsal view; 39 - left female chelicera, ventral view. Scale bars: (33-35, 37-39) 0.1 mm, (36) $1 \mathrm{~mm}$. Abbreviations: E — embolus; F — fossa; ID — insemination duct; RTA — retrolateral tibial apophysis; TA — terminal apophysis; VTA - ventral tibial apophysis.

Рис. 33-39. Копулятивные органы и габитус Laufeia squamata (Żabka, 1985), Salticidae, из Вьетнама (дер. Нуотсок, пров. Хатинь; см. Карту: 9): 33 - пальпа самца, вид снизу; 34 - тоже, сзади-латерально; 35 - эмболярный отдел, вид сверху; 36 - габитус самца; 37 - эпигина, вид снизу; 38 - сперматека, вид сверху; 39 - левая хелицера самки, вид снизу. Масштаб: (33-35, 37-39) 0,1 мм, (36) 1 мм. Сокращения: E - эмболюс; F — фосса; ID — копулятивный канал; RTA - задне-латеральный голенный отросток; TA — терминальный апофиз; VTA — вентральный голенный отросток. 
legs I stronger and longer than other legs. Legs III and IV yellow, with brown (semi)rings. Palpal structure as in Figs 33-35: both retrolateral and ventral tibial apophyses present; proximal tegular lobe present; the embolic division consists of both the sharpened, finger-shaped embolus and toothshaped terminal apophysis directed retro-laterad.

FEMALE. Measurements. Carapace 2.25 long, 1.63 wide and 0.80 high at PLE. Ocular area 1.25 long, 1.45 wide anteriorly and 1.38 wide posteriorly. Diameter of AME 0.50 . Clypeus height 0.08 , chelicera length 0.60 . Abdomen 2.30 long, 1.48 wide. Length of leg segments: I: $1.13+0.63+0.75$ $+0.75+0.40$; II: $1.08+0.53+0.53+0.68+0.40 ;$ III: $1.25+$ $0.58+0.70+1.02+0.43 ;$ IV: $1.43+0.45+1.00+1.18+0.45$ Leg spination. Leg I: Fm d 0-1-1-2; Tb pr 1ap, v 2-0-2ap; Mt v 2-2ap. Leg II: Fm d 0-1-1-3; Tb pr 0-1, rt 1-1, v 1-1ap; Mt v 2-2ap. Leg III: Fm d 0-1-1-3; Pt rt 0-1-0; Tb pr and rt 1-1, v 10 ; Mt pr and rt 1-0-2ap, v 2-0-2ap. Leg IV: Fm d 0-1-1-3; Pt rt $0-1-0 ;$ Tb pr and rt 1-1, v 1-0-2ap; Mt pr 1-0-2ap, rt 1-1-0-2ap, v 1-2ap. Coloration in alcohol. Carapace light brown, with yellowish eye field, a yellow median band and a dark brown marginal line; black around eyes. Carapace densely covered with white adpressed scales. Clypeus yellowish, densely covered with white hairs. Sternum yellow, covered with white hairs. Maxillae, labium and chelicerae yellow. Abdomen yellow, with dense brown speckles. Book-lung covers yellow; spinnerets light brown. All legs yellow, with brown (semi)rings. Palps entirely yellow, covered with white hairs. Epigyne and spermathecae as in Figs 37-38: with two shallow, symmetrical fossae (= epigynal windows); short, C-shaped insemination ducts; large, retort-shaped receptacles.

\section{Menemerus bivittatus (Dufour, 1831)}

MATERIAL. VIETNAM: 1 (BMNH), Dong Nai Prov., Cat Tien Nat. Park ( $\left.11^{\circ} 24.550^{\prime} \mathrm{N}, 107^{\circ} 24.247^{\prime} \mathrm{E}\right)$ [19], on wall outside building, 19.02.2012, J. Beccaloni; 1 O$^{7}$ (MMUE, G7565.19), Dong Nai Prov., Cat Tien N.P. $\left(11^{\circ} 25^{\prime} 19^{\prime \prime} \mathrm{N}, 107^{\circ} 25^{\prime} 41^{\prime \prime} \mathrm{E}\right)$ [19], December 2002, A.V. Abramov; $1 \mathrm{O}^{7}$ (ZMMU), Ba Ria - Vung Tau Prov., c. $1.5 \mathrm{~km} \mathrm{~S}$ of Bing Rieng Vil., Binh Chau - Phuoc Buu Nat. Res. $\left(10^{\circ} 32^{\prime} \mathrm{N}\right.$, $107^{\circ} 29^{\prime}$ E) [21], 50 m a.s.l., December 2010, A.V. Abramov.

COMMENTS. Pantropical species [WSC, 2015]; hitherto recorded from a number of localities in Vietnam by Żabka [1985], Peng, Li [2003] and Pham et al. [2004]: Hanoi, Cuc Phuong in Ninh Binh Prov., Quang Hoa in Cao Bang Prov., and Viet Lann Vil. in Ha Jiang Prov.

\section{Menemerus brachygnatus (Thorell, 1887)}

MATERIAL. VIETNAM: $10^{7}$ (ZMMU), Ba Ria - Vung Tau Prov., Central part of Con Son Island $\left(8^{\circ} 42^{\prime} \mathrm{N}, 106^{\circ} 35^{\prime} \mathrm{E}\right)$ [22], 5300 m a.s.l., June 2010, A.V. Abramov.

COMMENTS. Oriental species, distributed from Nepal and India in the west, to Vietnam and Japan in the east [WSC, 2015; Metzner, 2015]; hitherto recorded from Vietnam (Chine $-80 \mathrm{~km}$ SW of Hanoi, and Cuc Phuong in Ninh Binh Prov.) by Żabka [1985] and Pham et al. [2004].

Prószyński [1987] treated this species name as a junior synonym of Menemerus fulvus (L. Koch, 1878), yet the name was revalidated by Jastrzębski [1997].

\section{Myrmarachne globosa Wanless, 1978}

MATERIAL. VIETNAM: 1 \& (BMNH), Dong Nai Prov., Ca Tien Nat. Park $\left(11^{\circ} 24.550^{\prime} \mathrm{N}, 10^{\circ} 24.247^{\prime} \mathrm{E}\right)$ [19], in grass, 14.02.2012, J. Beccaloni.

COMMENTS. The species is known from Africa (Angola and Congo), southern China and Vietnam [Song et al., 1999; WSC, 2015; Metzner, 2015]; hitherto recorded from Vietnam (Chine - $80 \mathrm{~km} \mathrm{SW}$ of Hanoi) by Żabka [1985] and Pham et al. [2004].
Onomastus simoni Zabka, 1985

MATERIAL. VIETNAM: 1 \& (ZMMU), Ba Ria - Vung Tau Prov., Binh Chau - Phuoc Buu Nat. Res. (10³2’N, 107²9’E) [21], $50 \mathrm{~m}$ a.s.1., June 2007, A.V. Abramov.

COMMENTS. To date, this species has been known from the female holotype and from the type locality only: Vietnam, Cuc Phuong in Ninh Binh Prov. [Żabka, 1985], also listed by Pham et al. [2004]; it is the second record of the species after its original description (Map: 21).

\section{Pancorius crinitus Logunov et Jäger, sp.n.}

Figs 40-44.

MATERIAL.Holotype $\sigma^{7}$ (BMNH) from Vietnam, Dong Nai Prov., Cat Tien Nat. Park $\left(11^{\circ} 23.5771^{\prime} \mathrm{N}, 107^{\circ} 22.269^{\prime} \mathrm{E}\right)$ [19], low vegetation, 16.02.2012, J. Beccaloni. Paratypes: 2 o (BMNH), together with the holotype; $1 \sigma^{2}, 1$ (MMUE; G7569.1), same locality [19], night sweep netting at light trap area, 18.02.2012, J. Beccaloni; 3 O $^{7} \mathrm{O}^{\top}(\mathrm{BMNH})$, same locality [19], in plantation forest just outside the gate on the road to the minority Ta Lai Vil., 16.02.2012, J. Beccaloni; $1 \sigma^{7}$ (BMNH), same locality [19], swept from around vegetation in grounds of accommodation, 13.02.2012, J. Beccaloni.

ETYMOLOGY. From the Latin word 'crinitus' meaning 'hairy' and referring to the fact that male palps of the new species are densely covered with long white hairs.

DIAGNOSIS. This species differs from all the described Pancorius species in the following characters (for the comparative illustrations see Metzner [2015]): the male has the shortest and widest, thorn-shaped RTA directed dorsad (Fig. 41; not anteriad as in all other species); the female has the narrowest epigynal pocket situated near the epigastric furrow, looking like a transverse chitinous rim (Fig. 44; all other species for which the females are described have one/two clearly marked epigynal pockets); the conformation of spermathecae of the new species is also diagnostic (Fig. 43).

DISTRIBUTION. The type locality (Cat Tien National Park) only (Map: 19).

DESCRIPTION. MALE (the holotype). Measurements. Carapace 2.55 long, 2.20 wide and 1.45 high at PLE. Ocular area 1.65 long, 2.03 wide anteriorly and 1.95 wide posteriorly. Diameter of AME 0.63. Clypeus height 0.18, chelicera length 0.88. Abdomen 2.35 long, 1.70 wide. Length of leg segments: I: $1.75+0.85+1.30+0.95+0.60$; II: $1.70+0.75+1.10+0.90$ +0.55 ; III: $2.10+0.90+1.20+1.25+0.60 ;$ IV: $1.65+0.70$ $+1.10+1.30+0.60$. Leg spination. Leg I: Fm d 0-1-1-5; Pt pr and rt 0-1-0; Tb pr 1-1-1-1ap, rt 1-1-1, v 2-2-2ap; Mt pr and rt 1-1ap, v 2-2ap. Leg II: Fm d 0-1-2-5; Pt pr and rt 0-1-0; Tb pr 1-1-1-1ap, rt 1-1-1, v 2-2-2ap; Mt pr and rt 1-1ap, v 2-2ap. Leg III: Fm d 0-1-3-5; Pt pr and rt 0-1-0; Tb d 1-0, pr and rt 1-1-11, v 1-0-2ap; Mt pr 1-0-2p, v 2-0-2ap. Leg IV: Fm d 0-1-2-5; Pt pr and rt 0-1-0; Tb d 1-0, pr and rt 1-1-1-1, v 1-0-2ap; Mt d 0-1-0, pr and rt 1-0-2ap, v 1-0-2ap. Coloration in alcohol. Carapace yellow, with black around eyes; eye field and thorax behind the fovea sparsely covered with long brown scales; there is a wide marginal band of the carapace consisted of the long brown scales; both sides of the carapace with large white spots of long white scales; clypeus yellow, tinged with brown and with few thick, club-shaped, protruding white hairs. Sternum bright yellow. Maxillae and labium yellow, tinged with brown. Chelicerae brownish yellow, anteriorly with sparse, thick and club-shaped, protruding white hairs. Abdomen entirely yellow, with V-shaped figure made of wide greyish orange bands. Book-lung covers yellow; spinnerets grey. All legs yellow, with brown patches and (semi)rings of long, adpressed brown hairs. Legs I and I darker than other legs, with their femora anteriorly and patellae and tibiae anteriorly and 
ventrally densely covered with brown hairs. Palps yellow, densely covered with long white hairs, palpal structure as in Figs 40-41: short, cone-shaped tibial apophysis; tegulum round and flat, with a short proximal-ventral outgrowth; embolus relatively short, thorn-shaped.

FEMALE (the paratype collected together with the holotype). Measurements. Carapace 2.60 long, 2.05 wide and 1.40 high at PLE. Ocular area 1.60 long, 1.95 wide anteriorly and 1.90 wide posteriorly. Diameter of AME 0.60. Clypeus height 0.10 , chelicera length 0.80 . Abdomen 3.00 long, 2.05 wide. Length of leg segments: I: $1.55+0.90+1.15+0.75+$ $0.55 ;$ II: $1.45+0.80+1.10+0.75+0.55 ;$ III: $2.00+0.85+$ $1.10+1.00+0.70 ;$ IV: $1.80+0.75+1.05+1.25+0.60$. Leg spination. Leg I: Fm d 0-1-1-4; Pt pr 0-1-0; Tb pr 1-1, v 2-22ap; Mt v 2-2ap. Leg II: Fm d 0-1-2-5; Pt pr 0-1-0; Tb pr 11-1, v 2-2-2ap; Mt pr 1-1, v 2-2ap. Leg III: Fm d 0-1-2-4; Pt pr and rt 0-1-0; Tb pr and rt 1-1-1, v 1-0-2ap; Mt pr and rt 10-2p, v 2-0-2ap. Leg IV: Fm d 1-1-3; Pt pr and rt 0-1-0; Tb pr and rt 1-1-1, v 1-0-2ap; Mt pr and rt 1-1-2ap, v 1-0-2ap. Coloration in alcohol as in the male holotype, but lighter and differs from it as follows: carapace without large white spots of hairs on its sides; clypeus yellow and densely covered with white hairs; V-shaped pattern on dorsum grey (the second female that was at our disposal has grey-orange pattern); all legs and palps entirely yellow. Chelicera with a unidentate retromarginal tooth (Fig. 42). Epigyne and spermathecae as in Figs 43-44: epigynal plate flat, with two slit-shaped copulatory openings; very shallow and wide epigynal pocket is situated near the epigastric furrow; insemination ducts wide and short; receptacles ball-shaped, only slightly wider than the insemination ducts.

Colour variation. Males of this species display a strong colour variation and seem to exist in two colour morphs: the lighter (yellow) variant as that described above for the holotype, and the darker (brown) variant as that of the male paratypes available in the type series. The darker morph has brow carapace, with yellow-brown eye field; all legs, including their coxae brown to dark brown (except for the coxae IV which are yellow); palpal femora brown to dark brown, with remaining segment yellow; abdomen entirely dark grey, with a short longitudinal yellowish stripe in the area of cardiac mark; book-lungs and spinnerets dark grey.
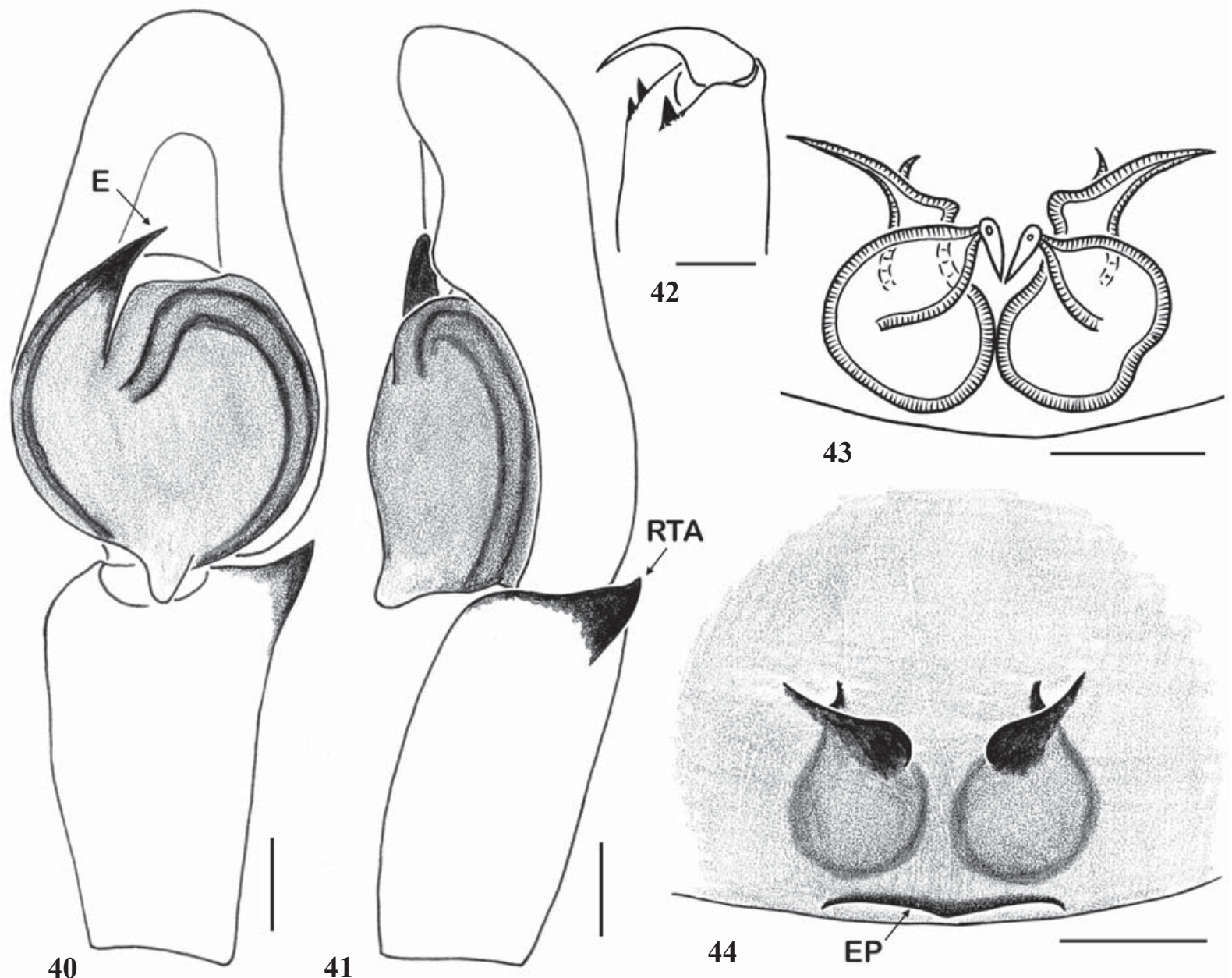

41

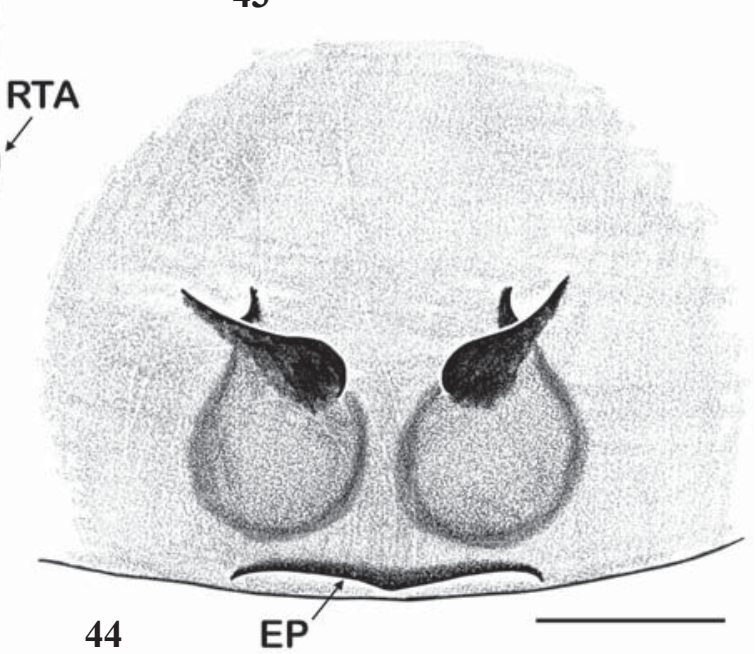

Figs 40-44. Copulatory organs of Pancorius crinitus sp.n. ( $\sigma^{7}$ holotype, 9 paratype), Salticidae: 40 - male palp, ventral view; $41-$ ditto, retrolateral view; 42 - left female chelicera, ventral view; 43 - spermathecae, dorsal view; 44 - epigyne, ventral view. Scale bars: (40-41, 43-44) $0.1 \mathrm{~mm},(42) 0.25 \mathrm{~mm}$. Abbreviations: E - embolus; EP - epigynal pocket; RTA - retrolateral tibial apophysis.

Рис. 40-44. Копулятивные органы Pancorius crinitus sp.n. (О7 голотип, 9 паратип), Salticidae: 40 — пальпа самца, вид снизу; 41 тоже, сзади-латерально; 42 - левая хелицеар самки, вид снизу; 43 - сперматека, вид сверху; 44 - эпигина, вид снизу. Масштаб: (40-41, 43-44) 0,1 мм, (42) 0,25 мм. Сокращения: Е — эмболюс; EP — эпигинальный карман; RTA — задне-латеральный голенный отросток. 
Pancorius magnus Żabka, 1985

MATERIAL. VIETNAM: 2 o $^{7}, 1$ ( (MMUE, G7565.22), Ba Vi Distr., c. $50 \mathrm{~km} \mathrm{~W}$ of Hanoi, Ba Vi Nat. Park, nr. Ba Vi Resort $\left(21^{\circ} 04^{\prime} 57.9^{\prime \prime} \mathrm{N}, 105^{\circ} 22^{\prime} 54.1^{\prime \prime} \mathrm{E}\right)$ [6], 35-400 m a.s.1., May 2013, A.V. Abramov; $20^{\top} 0^{7}$ (ZMMU), Ha Tinh Prov., Huong Son Distr., Son Kim Commune, c. $10 \mathrm{~km} \mathrm{~S}$ of Nuoc Sot Vil. $\left(18^{\circ} 22^{\prime} \mathrm{N}\right.$, 105¹3'E) [9], 200 m a.s.1., 11-26.04.2000, A.V. Abramov.

COMMENTS. Poorly documented Oriental species, to date recorded from India (Darjeeling), Nepal, Singapore, Taiwan and Vietnam [WSC, 2015; Metzner, 2015]; hitherto recorded from Vietnam (Cuc Phuong in Ninh Binh Prov., and Vinh Phu) by Żabka [1985], also listed by Pham et al. [2004].

Phintella bifurcilinea (Bösenberg et Strand, 1906) Figs 45-46.

MATERIAL. VIETNAM: $1 \sigma^{7}$ (BMNH), Dong Nai Prov., Cat Tien Nat. Park $\left(11^{\circ} 24.550^{\prime} \mathrm{N}, 107^{\circ} 24.247^{\prime} \mathrm{E}\right)$ [19], swept from foliage, 13.02.2012, J. Beccaloni.

COMMENTS. Oriental species, to date known from southern China, Korea, Japan and Vietnam [Song et al., 1999; WSC, 2015; Metzner, 2015]; hitherto recorded from a number of localities in Vietnam by Żabka [1985] and Peng, Li [2003], also listed by Pham et al. [2004]: Luc Yen in Yen Bai Prov., Sac Ha Vil. in Cao Bang Prov., Viet Lann Vil. in Ha Jiang Prov., and Bac Thai.

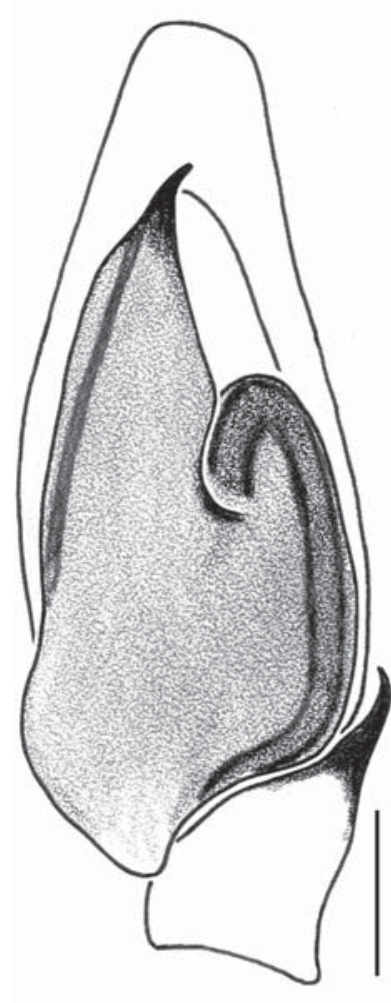

45

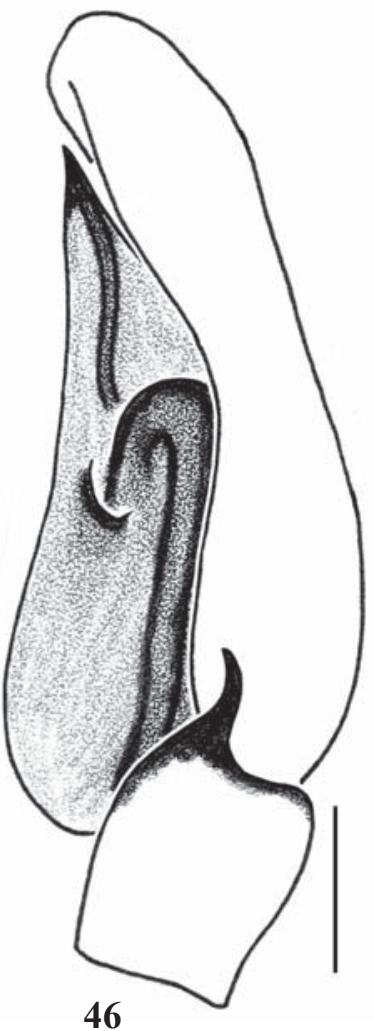

46
Figs 45-46. Male copulatory organ of Phintella bifurcilinea (Bösenberg et Strand, 1906), Salticidae, from Vietnam (Cat Tien Nat. Park in Dong Nai Prov.; see Map: 19): 45 — male palp, ventral view; 46 - ditto, retrolateral view. Scale bars: $0.1 \mathrm{~mm}$.

Рис. 45-46. Копулятивный орган самца Phintella bifurcilinea (Bösenberg et Strand, 1906), Salticidae, из Вьетнама (нац. парк Катьен в пров. Донгнай; см. Карту: 19): 45 - пальпа самца, вид снизу; 46 - тоже, сзади-латерально. Масштаб: 0,1 мм.
Plexippus paykulli (Audouin, 1826)

MATERIAL. VIETNAM: 1 (MMUE, G7565.13), Phu Tho Prov., Thanh Son Distr., Xuan Son Nat. Park $\left(21^{\circ} 08^{\prime} 11^{\prime \prime} \mathrm{N}\right.$, $104^{\circ} 56^{\prime} 11^{\prime \prime}$ E) [5], 300-400 m a.s.1., July 2014, A.V. Abramov; 2 $\sigma^{7} \sigma^{7}$ (MMUE, G7565.14), Lang Son Prov., Huu Lung Distr., nr. Huu Len Vil., Huu Lien Nat. Res. $\left(21^{\circ} 39^{\prime} 38^{\prime \prime} \mathrm{N}, 106^{\circ} 21^{\prime} 45^{\prime \prime} \mathrm{E}\right)$ [8], $230 \mathrm{~m}$ a.s.1., 8-13.11.2012, A.V. Abramov; 1 O $^{7}$ (MMUE, G7565.15), Ha Tinh Prov., Hong Linh, Dau Lieu (18²9'57.5' N, $105^{\circ} 44^{\prime} 03.3^{\prime \prime}$ E) [10], $26 \mathrm{~m}$ a.s.1., 5.05.2015, A.V. Abramov.

COMMENTS. Cosmopolitan species [WSC, 2015]; hitherto recorded from a number of localities in Vietnam by Simon [1903], Hogg [1922: sub. Menemerus crassus], Żabka [1985] and Pham et al. [2004]: Hanoi (incl. Thong Nhat), Phuc-Son in Annam, and Dran in Lam Dong Prov.

Plexippus petersi (Karsch, 1878)

MATERIAL. VIETNAM: $1 \sigma^{\top}$ (ZMMU), Ha Tinh Prov., Cam Xuyen Distr., Ke Go Nat. Res., nr. Mui Tru Station (18 $06^{\prime} 30^{\prime \prime} \mathrm{N}$, $106^{\circ} 01^{\prime} 01^{\prime \prime}$ E) [11], $40 \mathrm{~m}$ a.s.l., 7-14.04.2015 A.V. Abramov; 1 $O^{7}$ (MMUE, G7565.17), Kon Tum Prov., eastern part of Chu Mom

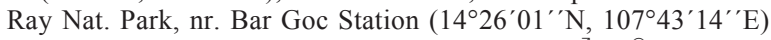
[13], 710 m a.s.1., May 2014, A.V. Abramov; 1 o , 1 ( (ZMMU), Dong Nai Prov., Cat Tien N.P. $\left(11^{\circ} 25^{\prime} 19^{\prime \prime} N, 107^{\circ} 25^{\prime} 41^{\prime \prime}\right.$ E) [19], December 2002, A.V. Abramov; $10^{7}, 1$ (MMUE, G7565.16), Ba Ria - Vung Tau Prov., Central part of Con Son Island $\left(8^{\circ} 42^{\prime} \mathrm{N}\right.$, $106^{\circ} 35^{\prime} \mathrm{E}$ ) [22], 5-300 m a.s.l., June 2010, A.V. Abramov.

COMMENTS. Widespread species in the (sub)tropical regions of the Old World [WSC, 2015; Metzner, 2015]; hitherto recorded from Vietnam (Bac Thai, and Hanoi - incl. Bach Thao and Thong Nhat) by Żabka [1985] and Pham et al. [2004].

\section{Portia fimbriata (Doleschall, 1859)}

MATERIAL. VIETNAM: 1 + (ZMMU), Ba Ria - Vung Tau

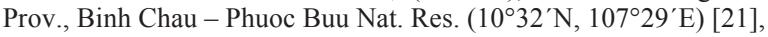
$50 \mathrm{~m}$ a.s.1., June 2007, A.V. Abramov.

COMMENTS. Widespread species in the (sub)tropical regions of the Old World [WSC, 2015; Metzner, 2015]; first record for Vietnam (Map: 21).

\section{Portia labiata (Thorell, 1887) Figs 47-51.}

MATERIAL. VIETNAM: $10^{\top}, 1+$ (BMNH), Dong Nai Prov., Cat Tien Nat. Park $\left(11^{\circ} 24.550^{\prime} \mathrm{N}, 107^{\circ} 24.247^{\prime} \mathrm{E}\right)$ [19], 1316.02.2012, J. Beccaloni.

COMMENTS. Oriental species, known from India and Sri Lanka in the west, throughout southern China to the Philippine and New Guinea in the east [WSC, 2015; Metzner, 2015]; first record for Vietnam (Map: 19).

The studied specimens indeed belong to P. labiata (cf. Figs 47-51 and figs 10, A-C, 11, A-C in Wanless [1978]). It is worth mentioning that the species Portia quei Żabka, 1985 described and recorded from Vietnam (Phu Que, Hanoi, and Tab Linch Vil. in Son Tay Prov.) [Żabka, 1985; Peng, Li, 2003] and then also recorded from a number of localities in southern China [Song et al., 1999] seems to be a junior synonym of $P$. labiata. Although the original illustrations by Żabka [1985: figs 497-498] show no ventral tegular spine, which is characteristic of the males of $P$. labiata (Figs 47-48), the subsequent illustrations of $P$. quei by Chinese authors [e.g., Song et al., 1999: fig. 311,L] show such a spine in the Chinese specimens. The female copulatory organs of the supposed female of $P$. quei are also identical with those of $P$. labiata (cf. Figs $50-51$ and figs $312, \mathrm{~F}-\mathrm{G}$ in Song et al. [1999]). A formal synonymy of both names is postponed until the holotype of $P$. quei has been re-examined. 

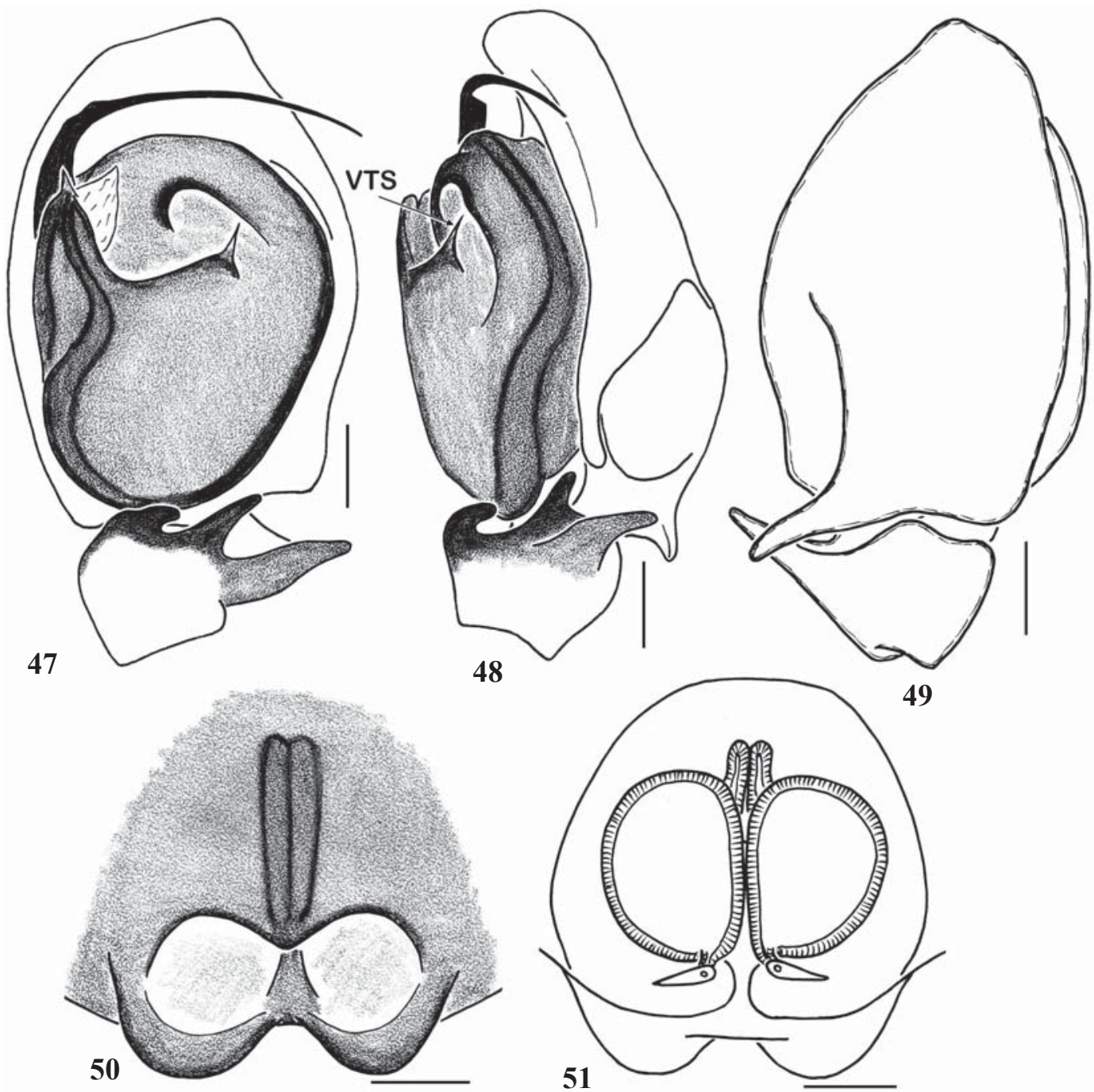

Figs 47-51. Copulatory organs of Portia labiata (Thorell, 1887), Salticidae, from Vietnam (Cat Tien Nat. Park in Dong Nai Prov.; see Map: 19): 47 - male palp, ventral view; 48 - ditto, retrolateral view; 49 - ditto, dorsal view; 50 - epigyne, ventral view; 51 spermathecae, dorsal view. Scale bars: $0.1 \mathrm{~mm}$. Abbreviation: VTS — ventral tegular spine.

Рис. 47-51. Копулятивные ограны Portia labiata (Thorell, 1887), Salticidae, из Вьетнама (нац. парк Катьен в пров. Донгнай; см. Карту: 19): 47 — пальпа самца, вид снизу; 48 - тоже, сзади-латерально; 49 - тоже, сверху; 50 - эпигина, вид снизу; 51 сперматека, вид сверху. Масштаб: 0,1 мм. Сокращение: VTS - вентральный тегулярный шип.

\section{Ptocasius weyersi Simon, 1885}

Figs 52-56.

MATERIAL. VIETNAM: $1 \sigma^{7}, 1 \%$ (BMNH), Dong Nai Prov., Cat Tien Nat. Park $\left(11^{\circ} 24.550^{\prime} \mathrm{N}, 107^{\circ} 24.247^{\prime} \mathrm{E}\right)[19], \mathrm{O}^{\prime}-$ on the ground, $q$ - sweep netting of foliage, 13-16.02.2012, J. Beccaloni.

DIAGNOSIS. Easily distinguished from all other Ptocasius species (for the comparative illustrations see Metzner [2015]) by the flat and round tegulum, with the embolus originating at 3 hours (Fig. 52) in the male and by presence and shape of the singular central epigynal pocket (Fig. 54); the conformation of the spermathecae is also diagnostic (Fig. $55)$.

COMMENTS. $P$. weyersi is the type species of the poorly diagnosed genus Ptocasius Simon, 1885 and to date has been known from the male only [Żabka, 1985: figs 530-534]. The newly described female of the type species allows us to clarify the generic definition, particularly by the fact that the female has the singular, central, blind-ending epigynal pock- et (Fig. 54), whereas almost all other described Ptocasius species, except for the Chinese P. montiformis Song, 1991 [see Song et al., 1999: figs 313,T-U], have two separated epigynal pockets, as in the species of the closely related genus Yaginumaella Prószyński, 1979 (see Metzner [2015] for the comparative illustrations). Thus, the old-standing problem of whether Ptocasius and Yaginumaella are congeneric or not is to be reconsidered in the light of finding of the female of $P$. weyersi. The matter requires a special attention in the future.

DISTRIBUTION. To date, the species has been known from the males from Indonesia (Sumatra) and Singapore [Metzner, 2015]; first record for Vietnam (Map: 19).

DESCRIPTION. MALE. Measurements. Carapace 3.70 long, 2.80 wide and 2.25 high at PLE. Ocular area 1.90 long, 2.03 wide anteriorly and 2.48 wide posteriorly. Diameter of AME 0.78. Clypeus height 0.15 , chelicera length 1.63 . Abdomen 4.00 long, 1.90 wide. Length of leg segments: I: $2.45+$ $1.40+1.75+1.20+0.70 ;$ II: $2.00+1.20+1.40+1.05+0.60$; 
III: $2.25+1.15+1.25+1.45+0.70 ;$ IV: $2.20+0.95+1.45$ $+1.50+0.75$. Leg spination. Leg I: Fm d 0-1-1-4; Pt pr and rt 0-1-0; Tb pr and rt 1-1, v 2-2-2ap; Mt pr and rt 1ap, v 2-2ap. Leg II: Fm d 0-1-2-5; Pt pr and rt 0-1-0; Tb d 1-0-0-2, pr and rt 1-1-1, v 1-0-2ap; Mt pr and rt 1-0-2ap, v 2-0-2ap. Leg III: Fm d 0-1-2-5; Pt pr and rt 0-1-0; Tb d 1-0-0-2, pr and rt 1-11, v 1-0-2ap; Mt pr and rt 1-0-2p, v 2-0-2ap. Leg IV: Fm d 01-2-5; Pt pr and rt 0-1-0; Tb d 1-0-0-2, pr and rt 1-1-1, v 1-02ap; Mt pr and rt 1-1-2ap, v 1-0-2ap. Coloration in alcohol. Carapace brown, but slightly yellowish behind PLEs, sparsely covered with brown hairs; sides of carapace with large and wide patches of white scales. Sternum brownish. Labium and maxillae brown, with yellow apexes. Chelicerae dark brown. Abdomen elongated pear-shaped, brownish on its sides, anteriorly covered with brownish hairs; dorsum with an elongated, interrupted yellow stripe; venter yellow, with a wide elongated brownish stripe. Book-lung covers yellow, spinnerets brownish. All legs: femora brown, remaining segments yellow. Palps brownish, palpal structure as in Figs 52-53: singular RTA with a sharpened tip that is slightly bent dorsad; tegulum round and flat; long, whip-shaped embolus originates at 3 hours.
FEMALE. Measurements. Carapace 2.50 long, 1.85 wide and 1.25 high at PLE. Ocular area 1.45 long, 1.78 wide anteriorly and 1.85 wide posteriorly. Diameter of AME 0.60. Clypeus height 0.08 , chelicera length 0.98 . Abdomen 3.20 long, 1.90 wide. Length of leg segments: I: $1.23+0.75+0.85$ $+0.55+0.55$; II: $1.10+0.75+0.70+0.55+0.43$; III: $1.35+$ $0.73+0.78+0.78+0.50 ;$ IV: $1.43+0.68+0.98+0.98+$ 0.53. Leg spination. Leg I: Fm d 0-1-2-3; Pt pr 0-1-0; Tb pr 1-1, v 2-2-2ap; Mt v 2-2ap. Leg II: Fm d 0-1-2-5; Pt pr 0-10 ; Tb pr 1-1, v 2-2-2ap; Mt pr 1-1ap, v 2-2ap. Leg III: Fm d 0-1-1-4; Pt pr and rt 0-1-0; Tb pr 1-1, rt 1-1-1, v 1-2ap; Mt pr and rt 1-2p, v 2-2ap. Leg IV: Fm d 0-1-1-3; Pt pr and rt 0-10 ; Tb pr 0-1-1, rt 1-1-1, v 2ap; Mt pr and rt 1-1-2ap, v 1-02ap. Coloration in alcohol as in the male, but palps are entirely yellow. Epigyne and spermathecae as in Figs 54-56: two large, symmetrical copulatory openings facing each other; central blind-ending epigynal pocket present; insemination ducts relatively long and wide; receptacles pear-shaped.

\section{Rhene albigera (C.L. Koch, 1848)}

MATERIAL. VIETNAM: $1 \sigma^{7}, 1$ juv. (ZMMU), Dong Nai Prov., Cat Tien N.P. $\left(11^{\circ} 25^{\prime} 19^{\prime \prime} N, 107^{\circ} 25^{\prime} 41^{\prime \prime}\right.$ E) [19], December 2002, A.V. Abramov.
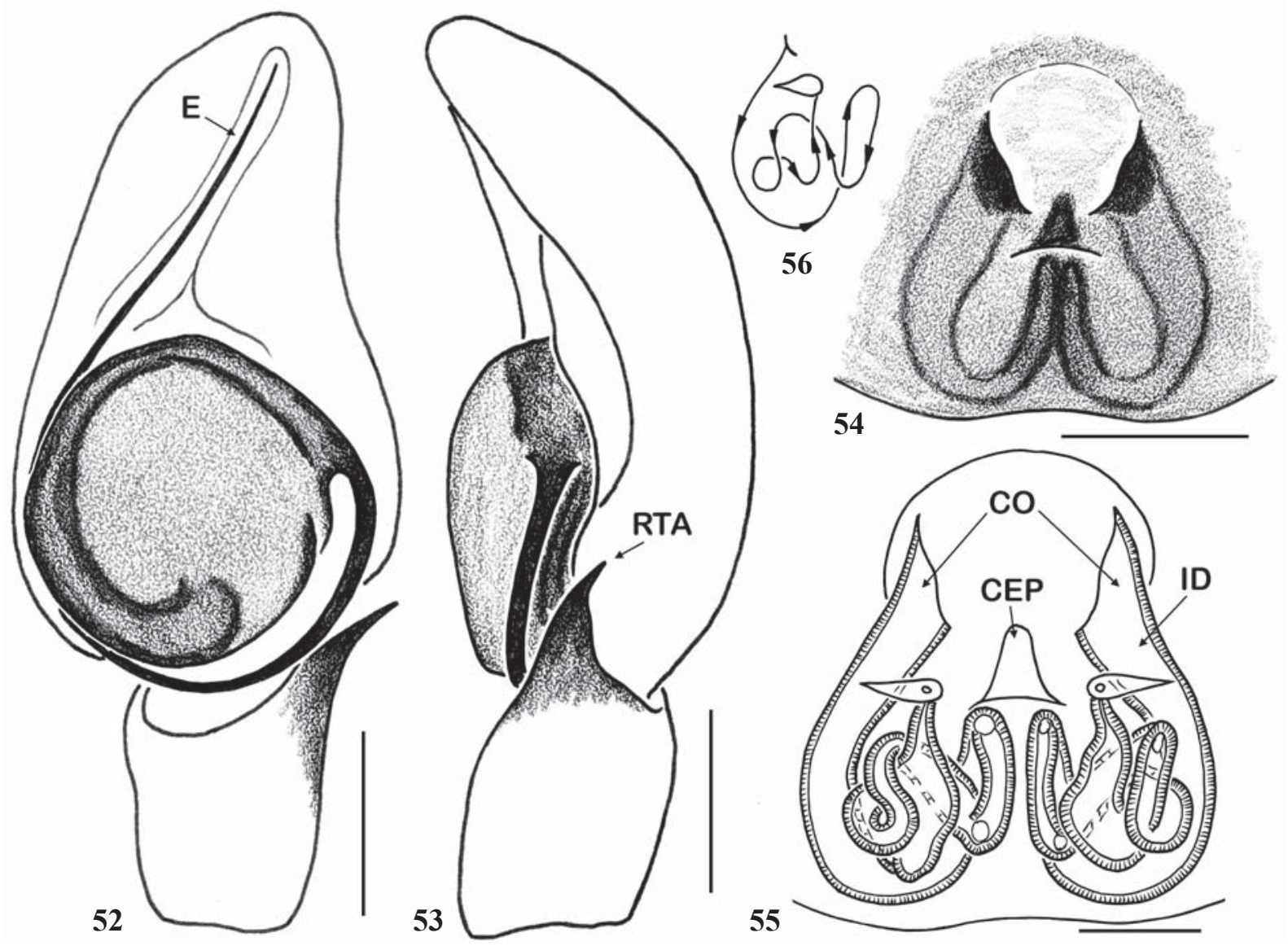

Figs 52-56. Copulatory organs of Ptocasius weyersi Simon, 1885, Salticidae, from Vietnam (Cat Tien Nat. Park in Dong Nai Prov.; see Map: 19): 52 - male palp, ventral view; 53 - ditto, retrolateral view; 54 - epigyne, ventral view; 55 - spermathecae, dorsal view; 56 diagrammatic course of the insemination ducts. Scale bars: $0.1 \mathrm{~mm}$. Abbreviations: CEP — central epigynal pocket; CO — copulatory opening; E - embolus; ID — insemination duct; RTA — retrolateral tibial apophysis.

Рис. 52-56. Копулятивные органы Ptocasius weyersi Simon, 1885, Salticidae, из Вьетнама (нац. парк Катьен в пров. Донгнай; см. Карту: 19): 52 - пальпа самца, вид снизу; 53 - тоже, задне-латерально; 54 - эпигина, вид снизу; 55 - сперматека, вид сверху; 56 - схема протоков копулятивных каналов. Масштаб: 0,1 мм. Сокращения: СЕР — центральный эпигинальный карман; СО копулятивное отверстие; E — эмболюс; ID — копулятивные каналы; RTA — задне-латеральные голенный отросток. 
COMMENTS. Oriental species, known from Nepal and India in the west, throughout southern China to South Korea and Japan in the east, southward to Sumatra [WSC, 2015; Metzner, 2015]; hitherto recorded from a number of localities in Vietnam by Żabka [1985], Peng, Li [2003], and Pham et al. [2004]: Phu Que - $80 \mathrm{~km}$ NW of Vinh, Thang Ha in Hoa Binh Prov., Cuc Phuong in Ninh Binh Prov., and. Tan Linh Vil. in Son Tay Prov.

\section{Siler semiglaucus (Simon, 1901)}

MATERIAL. VIETNAM: $10^{\top}, 1$ (ZMMU), Dong Nai Prov., Cat Tien N.P. $\left(11^{\circ} 25^{\prime} 19^{\prime \prime} \mathrm{N}, 107^{\circ} 25^{\prime} 41^{\prime \prime} \mathrm{E}\right)$ [19], December 2002, A.V. Abramov.

COMMENTS. Under-recorded Oriental species, known from Sri Lanka and Nepal in the west to the Phillipines in the east, and to Sumatra in the south [WSC, 2015; Metzner, 2015]; hitherto recorded from Vietnam (Phuc-Son in Annam) by Simon [1903: sub. Cyllobeus s.].

Stenaelurillus abramovi Logunov, 2008

MATERIAL. VIETNAM: 1 ○', 1 \% (MMUE, G7565.18), Ba Ria - Vung Tau Prov., Binh Chau - Phuoc Buu Nat. Res. $\left(10^{\circ} 32^{\prime} \mathrm{N}\right.$, $\left.107^{\circ} 29^{\prime} \mathrm{E}\right)$ [21], $50 \mathrm{~m}$ a.s.1., November 2010, A.V. Abramov.

COMMENTS. To date, this species has been described and known from the type locality only: Vietnam, Binh Chau - Phuoc Buu Nat. Res. [Logunov, 2008] (Map: 21).

\section{Telamonia festiva Thorell, 1887}

MATERIAL. VIETNAM: $2 \sigma^{\top} \mathrm{O}^{\top}$ (BMNH), Dong Nai Prov., Cat Tien Nat. Park $\left(11^{\circ} 24.550^{\prime} \mathrm{N}, 107^{\circ} 24.247^{\prime} \mathrm{E}\right)$ [19], 18.02.2012, J. Beccaloni.

COMMENTS. Oriental species, known from southern China to Indonesia and Malaysia [WSC, 2015; Metzner, 2015]; hitherto recorded from a number of localities in Vietnam by Simon [1903: sub. Viciria tenebrifera and $V$. $t$ nigrina], Żabka [1985], Peng, Li [2003] and Pham et al. [2004]: Phuc-Son in Annam, Chine - 80 km SW of Hanoi, Cuc Phuong in Ninh Binh Prov., Thang Ha in Hoa Binh Prov., Gao Bao Vil. in Ha Jiang Prov., and Chai river.

\section{Thiania subopressa Strand, 1907}

MATERIAL. VIETNAM: $40^{7} \sigma^{7}, 6$ 우 (ZMMU), Ha Tinh Prov., Huong Son Distr., Son Kim Commune, c. $10 \mathrm{~km} \mathrm{~S}$ of Nuoc Sot Vil. (18 $\left.22^{\prime} \mathrm{N}, 105^{\circ} 13^{\prime} \mathrm{E}\right)$ [9], $200 \mathrm{~m}$ a.s.l., 14-26.04.2000, A.V. Abramov; $10^{7}$ (MMUE, G7565.21), border between Gia Lai and Dak Lak Provinces $\left(13^{\circ} 22^{\prime} 52^{\prime \prime} \mathrm{N}, 108^{\circ} 07^{\prime} 31^{\prime \prime} \mathrm{E}\right)$ [14], c. $300 \mathrm{~m}$ a.s.1., dry dipterocarp forest, 10.04.2006, A.V. Abramov; $10^{7}$ (BMNH), Dong Nai Prov., Cat Tien Nat. Park $\left(11^{\circ} 24.550^{\prime} \mathrm{N}\right.$, $107^{\circ} 24.247^{\prime} \mathrm{E}$ ) [19], sweep netting of grassland, daytime, 13.02.2012, J. Cranfield.

COMMENTS. Oriental species, known from southern China, Japan (Okinawa) and Vietnam [WSC, 2015; Metzner, 2015]; hitherto recorded from Vietnam (Lao Cai, Bac Thai, and Hanoi, incl. Mai Lam) by Żabka [1985] and Pham et al. [2004].

ACKNOWLEDGEMENTS. We wish to thank Alexei V. Abramov (Zoological Institute, St. Petersburg), Jan Beccaloni (BMNH), Sergei L. Esyunin (PSU), and K. van Dorp and Jeremy Miller (both RMNH) for giving us an opportunity to study their Vietnamese spider collections. Alexei V. Abramov is also thanked for the help in preparing the map with collecting localities. Fieldworks of Alexei V. Abramov in Vietnam were supported by the Joint Vietnam-Russian Tropical Research and Technological Centre. Two anonymous referees are thanked for critical comments helping to improve the ms. Finaly, we are obliged to David Penney (Manchester, UK) for his kind help in editing the English of the final draft.

\section{References}

Barrion A.T., Litsinger J.A. 1995. Riceland Spiders of South and Southeast Asia. UK, Wallingford: CAB International. xix +700 pp.

Bayer S. 2014. Seven new species of Psechrus and additional taxonomic contributions to the knowledge of the spider family Psechridae (Araneae) // Zootaxa. Vol.3826. No.1. P.1-54. doi:10.11646/zootaxa.3826.1.1

Benjamin S.P. 2013. On the crab spider genus Angaeus Thorell, 1881 and its junior synonym Paraborboropactus Tang and Li, 2009 (Araneae: Thomisidae) // Zootaxa. Vol.3635. P.71-80. doi:10.11646/zootaxa.3635.1.7

Bohdanowicz A., Prószyński J. 1987. Systematic studies on East Palaearctic Salticidae (Araneae), IV. Salticidae of Japan // Ann. Zool. Warszawa. Vol.41. No.2. P.43-151.

Dankittipakul P., Jocqué R., Singtripop T. 2012. Systematics and biogeography of the spider genus Mallinella Strand, 1906, with descriptions of new species and new genera from southeast Asia (Araneae, Zodariidae) // Zootaxa. Vol.3369. P.1-327. and Vol.3395. P.46.

Davies V.T. 1994. The huntsman spiders Heteropoda Latreille and Yiinthi gen. nov. (Araneae: Heteropodidae) in Australia // Mem. Queensland Mus. Vol.35. P.75-122.

Deeleman-Reinhold C.L. 2001. Forest spiders of South East Asia: with a revision of the sac and ground spiders (Araneae: Clubionidae, Corinnidae, Liocranidae, Gnaphosidae, Prodidomidae and Trochanterriidae [sic]). Leiden: Brill. 591 pp.

Eusemann P., Jäger P. 2009. Heteropoda tetrica Thorell, 1897 variation and biogeography, with emphasis on copulatory organs (Araneae: Sparassidae) // Contr. Nat. Hist. Vol.12. P.499-516.

Hogg H.R. 1922. Some spiders from south Annam // Proc. Zool. Soc. London. Vol.1922. P.285-312.

Ikeda H. 1998. Spiders of the genus Laufeia (Araneae: Salticidae) from Japan // Acta Arachnologica. Vol.47. No.1. P.37-43.

Jäger P. 2003. Rhitymna Simon 1897: an Asian, not an African spider genus. Generic limits and descriptions of new species (Arachnida, Araneae, Sparassidae) // Senck. Biol. Bd.82. S.99-125.

Jäger P. 2007. Spiders from Laos with descriptions of new species (Arachnida: Araneae) // Acta Arachnol. Vol.56. P.29-58.

Jäger P. 2008. Revision of the huntsman spider genus Heteropoda Latreille 1804: species with exceptional male palpal conformations from southeast Asia and Australia (Arachnida, Araneae: Sparassidae: Heteropodinae) // Senck. Biol. Bd.88. S.239-310.

Jäger P. 2011. Revision of the spider genera Nilus O. PickardCambridge 1876, Sphedanus Thorell 1877 and Dendrolycosa Doleschall 1859 (Araneae: Pisauridae) // Zootaxa. Vol.3046. P. $1-38$.

Jäger P. 2012a. A review on the spider genus Argiope Audouin 1826 with special emphasis on broken emboli in female epigynes (Araneae: Araneidae: Argiopinae)// Beitr. Araneol. Bd.7. S.272331.

Jäger P. 2012b. Asian species of the genera Anahita Karsch 1879, Ctenus Walckenaer 1805 and Amauropelma Raven, Stumkat et Gray 2001 (Arachnida: Araneae: Ctenidae) // Zootaxa. Vol.3429. P.1-63.

Jäger P. 2014. Heteropoda Latreille, 1804: new species, synonymies, transfers and records (Araneae: Sparassidae: Heteropodinae) // Arthropoda Sel. Vol.23. No.2. P.145-188.

Jäger P. 2015. Conductor-less and vertically niched: new species of the genus Pseudopoda (Araneae: Sparassidae: Heteropodinae) from Myanmar // Arachnology. Vol.16. No.9. P.333-350.

Jäger P., Li S.Q., Krehenwinkel H. 2015. Morphological and molecular taxonomic analysis of Pseudopoda Jäger, 2000 (Araneae: Sparassidae: Heteropodinae) in Sichuan Province, China // Zootaxa. Vol.3999. No.3. P.363-392. doi:10.11646/zootaxa.3999.3.3

Jäger P., Praxaysombath B. 2009. Spiders from Laos: new species and new records (Arachnida: Araneae) // Acta Arachnol. Vol.58. P.27-51.

Jäger P., Praxaysombath B. 2011. Selenops muehlmannorum spec. nov. from southern Laos (Araneae: Selenopidae) // Zootaxa. Vol.2883. P.65-68. 
Jäger P., Pathoumthong B., Vedel V. 2006. First record of the genus Pseudopoda Jäger 2000 in Laos with description of new species (Arachnida, Araneae, Sparassidae) // Senck. Biol. Bd.86. S.219-228.

Jastrzębski P. 1997. Salticidae from the Himalayas. Genus Menemerus Simon, 1868 (Araneae: Salticidae) // Entomol. Basil. Vol.20. P.33-44.

Kuntner M. 2005. A revision of Herennia (Araneae: Nephilidae: Nephilinae), the Australasian 'coin spiders'// Inv. Syst. Vol.19. P.391-436.

Li S.Q., Zonstein S. 2015. Eight new species of the spider genera Raveniola and Sinopesa from China and Vietnam (Araneae, Nemesiidae) // ZooKeys. Vol.519. P.1-32. doi:10.3897/zookeys. 519.8784

Lin Y.C., Li S.Q. 2014. Mysmenidae (Arachnida, Araneae), a spider family newly recorded from Vietnam // Zootaxa. Vol.3826. No.1. P.169-194. doi:10.11646/zootaxa.3826.1.5

Liu J., Li S.Q., Jäger P. 2010. Huntsman spiders (Araneae: Sparassidae) from Xishuangbanna rainforest, China // Zootaxa. Vol.2508. P.56-64.

Logunov D.V. 2008. A new species of the genus Stenaelurillus Simon 1885 (Araneae: Salticidae) from Vietnam // Acta Arachnol. Vol.57. P.43-45.

Marusik Yu.M., Kovblyuk M.M. 2011. [Spiders (Arachnida, Aranei) of Siberia and Russian Far East]. Moscow: KMK Scientific Press. 344 pp. [in Russian]

Metzner H. 2015. Worldwide database of jumping spiders (Arachnida, Araneae, Salticidae); online at: http://www.jumpingspiders.com/ (accessed on15/09/2015).

Ono H. 1988. A revisional study of the spider family Thomisidae (Arachnida, Araneae) of Japan. Tokyo: National Science Museum. 252 pp.

Ono H., Thinh T.H., Pham S.D. 2012. Spiders (Arachnida, Araneae) recorded from Vietnam, 1837-2011// Mem. Nat. Mus. Nat. Sci. Vol.48. P.1-37.

Peng X.J., Li S.Q. 2003. New localities and one new species of jumping spiders (Araneae: Salticidae) from northern Vietnam // Raffles Bull. Zool. Vol.51. P.21-24.

Pham S.D. 2012. Provisional atlas: Cave arachnid biodiversity value in the Ha Long Bay, Vietnam - A world national heritage area. Hanoi. $45 \mathrm{pp}$.

Pham D.S. 2015. One new species of the genus Belisana Thorell, 1898 (Araneae, Pholcidae) from northern Vietnam // ZooKeys. Vol.480. P.41-47. doi:10.3897/zookeys.480.9046

Pham S.D., Con V.Q., Żabka M. 2004. [A preliminary checklist of the jumping spiders (Araneae, Salticidae) of Vietnam] // J. Biol. Vol.26. P.48-56. [in Vietnamese]

Prószyński J. 1987. Atlas rysunków diagnostycznych mniej znanych Salticidae 2. Zeszyty Naukowe Wyższej Szkoly Rolniczo-Pedagogicznej v Siedlcach. 172 pp.

Simon E. 1886. Arachnides recueillis par M. A. Pavie (sous chef du service des postes au Cambodge) dans le royaume de Siam, au
Cambodge et en Cochinchine // Actes Soc. Linn. Bordeaux. Vol.40. P.137-166.

Simon E. 1887. Etude sur les arachnides de l'Asie méridionale faisant partie des collections de l'Indian Museum (Calcutta). I. Arachnides recueillis à Tavoy (Tenasserim) par Moti Ram // J. Asiatic Soc. Bengal. Vol.56. P.101-117.

Simon E. 1889. Etudes arachnologiques. 21e Mémoire. XXXIII. Descriptions de quelques espèces receillies au Japon, par A. Mellotée // Ann. Soc. Entomol. France Vol.6. No.8. P.248-252.

Simon E. 1903. Histoire naturelle des araignées. Paris. Vol.2. P.6691080 .

Simon E. 1909. Etude sur les arachnides du Tonkin (1re partie) // Bull. Sci. France Belgique. Vol.42. P.69-147.

Song D.X., Zhu M.S., Chen J. 1999. The Spiders of China. Shijiazhuang: Hebei University of Science and Techology Publishing House. 640 pp.

Tang G., Yin C.M., Peng X.J., Ubick D., Griswold C. 2007. Five crab spiders of the genus Lysiteles from Yunnan Province, China (Araneae: Thomisidae) // Zootaxa. Vol.1480. P.57-68.

Tang G., Yin C.M., Peng X.J., Ubick D., Griswold C. 2008. The crab spiders of the genus Lysiteles from Yunnan Province, China (Araneae: Thomisidae) // Zootaxa. Vol.1742. P.1-41.

Tong Y.F., Li S.Q. 2013. The first goblin spiders of the genus Trilacuna from Vietnam (Araneae, Oonopidae) // Zootaxa. Vol.3709. No.3. P.277-284. doi:10.11646/zootaxa.3709.3.6

Wanless F.R. 1978. A revision of the spider genus Portia (Araneae: Salticidae) // Bull. Br. Mus. Nat. Hist. (Zool.) Vol.34. No.3. P.83-124.

WSC, 2015. World Spider Catalog. Natural History Museum Bern, online at: http://wsc.nmbe.ch, version 16.5 (accessed on 15/09/ 2015).

Yao Z.Y., Pham D.S., Li S.Q. 2012. A new species of the genus Pholcus (Araneae, Pholcidae) from Vietnam // Acta Zootaxon. Sinica. Vol.37. P.313-318.

Yao Z.Y., Pham D.S., Li S.Q. 2015. Pholcid spiders (Araneae: Pholcidae) from northern Vietnam, with descriptions of nineteen new species // Zootaxa. Vol.3909. No.1. P.1-82. doi:10.11646/zootaxa.3909.1.1

Żabka M. 1985. Systematic and zoogeographic study on the family Salticidae (Araneae) from Viet-Nam // Ann. Zool. Warszawa. Vol.39. P.197-485.

Zha Z.W., Pham D.S., Li S.Q. 2012. One new Calommata spider from Vietnam (Araneae, Atypidae) // Acta Zootaxon. Sinica. Vol.37. P.319-321.

Zhang Z.S., Li S.Q., Pham D.S. 2013. First description of combtailed spiders (Araneae: Hahniidae) from Vietnam // Zootaxa. Vol.3613. No.4. P.343-356. doi:10.11646/zootaxa.3613.4.2

Zhang J.X., Maddison W.P. 2015. Genera of euophryine jumping spiders (Araneae: Salticidae), with a combined molecular-morphological phylogeny // Zootaxa. Vol.3938. No.1. P.1-147. doi:10.11646/zootaxa.3938.1.1 